\title{
Possible Repair Mechanism for Hydrocarbon-Based Ionomers Following Damage by Radical Attack
} \author{
Thomas Nauser, ${ }^{2}$ (iD and Lorenz Gubler ${ }^{1, * * *, z^{(D)}}$ \\ ${ }^{1}$ Electrochemistry Laboratory, Paul Scherrer Institut, 5232 Villigen PSI, Switzerland \\ ${ }^{2}$ Laboratory of Inorganic Chemistry, ETH Zurich, 8093 Zurich, Switzerland \\ ${ }^{3}$ Laboratory of Physical Chemistry, ETH Zurich, 8093 Zurich, Switzerland
}

Tym de Wild, ${ }^{1,2,=, *}$ (1) Tamas Nemeth, ${ }^{1,2,=}$ (1) Tom M. Nolte, ${ }^{1,2, a}$ (1) Thomas J. Schmidt, ${ }^{1,3, * *}$ (다

\begin{abstract}
Polymer electrolyte fuel cell (PEFC) membranes are subject to radical-induced degradation. Antioxidant strategies for hydrocarbon-based ionomers containing aromatic units can focus on intermediates that are formed upon attack by hydroxyl radicals $\left(\mathrm{HO}^{\circ}\right)$. Among the different intermediates, the cation radical $\mathrm{P}^{+}$is the most promising target for repair, for example by cerium(III). For the "repair" reaction of $\mathrm{Ce}$ (III) with radicals of a poly $(\alpha$-methylstyrene sulfonate) oligomer we determined an activation energy of $(9 \pm 2) \mathrm{kJ} \mathrm{mol}^{-1}$ and a rate constant of $1.6 \cdot 10^{8} \mathrm{M}^{-1} \mathrm{~s}^{-1}$ at $80^{\circ} \mathrm{C}$ by pulse-radiolysis. For the reduction of $\mathrm{Ce}(\mathrm{IV})$ by hydrogen peroxide the activation energy was determined by stopped-flow as $(30 \pm 1) \mathrm{kJ} \mathrm{mol}^{-1}$ with a rate constant of $4.8 \cdot 10^{6} \mathrm{M}^{-1} \mathrm{~s}^{-1}$ at $80{ }^{\circ} \mathrm{C}$. These parameters are fed into a kinetics model to estimate the efficacy of the cerium (III)/(IV) redox couple as a catalytic repair agent in hydrocarbon-based fuel cell membranes. While cerium can mitigate polymer degradation, repair efficacy depends on the polymer degradation pathway and the nature and lifetime of the intermediates.

(C) 2021 The Author(s). Published on behalf of The Electrochemical Society by IOP Publishing Limited. This is an open access article distributed under the terms of the Creative Commons Attribution 4.0 License (CC BY, http://creativecommons.org/licenses/ by/4.0/), which permits unrestricted reuse of the work in any medium, provided the original work is properly cited. [DOI: 10.1149/ 1945-7111/abf9be]
\end{abstract}

Manuscript submitted January 15, 2021; revised manuscript received April 18, 2021. Published May 11, 2021. This paper is part of the JES Focus Issue on Proton Exchange Membrane Fuel Cell and Proton Exchange Membrane Water Electrolyzer Durability.

Supplementary material for this article is available online

Fuel cells have reached a certain degree of technical and economic maturity with application space in the range of residential and mobile sectors. Nevertheless, there is growing need of further development for significant market penetration, especially in the transportation sector. Japan's New Energy and Industrial Technology Development Organization (NEDO) has put forward challenging targets for automotive fuel cell systems by 2040 , specifically a single cell voltage of $0.85 \mathrm{~V}$ at a current density of $4.4 \mathrm{~A} \mathrm{~cm}^{-2}$ and a temperature of $120{ }^{\circ} \mathrm{C} .{ }^{1}$ Today's polymer electrolyte fuel cell (PEFC) technology is still largely based on materials that have been around for decades, such as perfluroalkylsulfonic acid (PFSA) ionomers in the membrane and catalyst layers, and carbon-supported nano-sized noble metal based particles as electrocatalyst. Gradual and steady advances have been made over the past two and a half decades. For the proton exchange membrane (PEM), it has been the introduction of reinforced materials, ${ }^{2}$ end-group stabilization, ${ }^{3}$ short side-chain ionomers, ${ }^{4,5}$ a reduction of thickness, ${ }^{6}$ and doping with radical scavengers. ${ }^{7,8}$ For the ionomer in the catalyst layer, there is a trend towards PFSA based materials with higher oxygen permeability. ${ }^{9}$ For the electrocatalyst, in particular for the sluggish oxygen reduction reaction (ORR), the main improvements have been the use of Pt-alloys with improved activity, ${ }^{10,11}$ high surface area carbon supports for improved nanoparticle dispersion, ${ }^{12}$ and engineering of the carbon porosity to minimize oxygen transport losses. ${ }^{13}$

Reaching the aforementioned NEDO targets may require a drastic technological step in the form of next-generation fuel cell materials and cell engineering. Hydrocarbon-based PEMs are often proposed as replacements for PFSA membranes. ${ }^{14}$ This class of materials encompasses a wide range of different polymers, most of which contain aromatic units in their main chain. ${ }^{15}$ Scheme 1

\footnotetext{
$=$ These authors contributed equally to this work.

*Electrochemical Society Student Member.

***Electrochemical Society Fellow.

***Electrochemical Society Member.

${ }^{\text {a }}$ Present address: Department of Environmental Science, Institute for Water and

Wetland Research, Radboud University Nijmegen, 6500 GL Nijmegen, The Netherlands.

${ }^{\mathrm{z} E}$ E-mail: lorenz.gubler@psi.ch
}

illustrates a generic structure of such an aromatic unit, where " $\mathrm{X}$ " is a linking unit, such as-(chemical bond), $-\mathrm{O}-($ ether $),-(\mathrm{C}=\mathrm{O})-$ (ketone), or $-\left(\mathrm{SO}_{2}\right)$ - (sulfone). The sulfonic acid group may be located on either the main chain or a side chain, which itself can be aromatic (Ar), aliphatic (R), or a mixture thereof. The key advantages of polyaromatic membranes are the expected lower cost, lower permeability of hydrogen and oxygen, and better mechanical robustness at temperatures above $90{ }^{\circ} \mathrm{C} .{ }^{16,17}$ In fact, until 2007, hydrocarbon membranes were used in the stack of Honda FCX hydrogen fuel cell demonstration vehicles. ${ }^{18}$ Their use, however, was discontinued and PFSA membranes were re-introduced. It appears that the stability and durability of these materials were considered insufficient. ${ }^{19} \mathrm{~A}$ further related challenge associated with hydrocarbon-based PEMs is their diminished performance under reduced relative humidity conditions, due to poor conductivity. With an adequate polymer architecture, such as multi-block copolymers, this short-coming can be somewhat mitigated. ${ }^{20}$ Hydrocarbon-based membranes have a much lower gas permeability than PFSA membranes and, therefore, have shown an improved chemical stability under accelerated stress test conditions in open circuit voltage (OCV) hold tests in many cases. ${ }^{21,22}$ However, if combined with relative humidity cycling, they typically show much lower durability. ${ }^{14}$ This is a result of both higher water uptake and stiffness of the material and an embrittlement caused by crosslinking, which is triggered by oxidation of the polymer chain. ${ }^{23}$ Recent results have shown that a tenfold increase in wet-dry cycling durability of an aromatic PEM can be achieved when mechanically reinforced. ${ }^{24}$ Nevertheless, gradual oxidative chain degradation is still expected to take place.

Hydrocarbon based ionomers are inherently susceptible to radical induced degradation, which leads to oxidation, material embrittlement, and polymer chain fragmentation. Under the operating conditions of a PEFC, the radical species $\mathrm{HO}^{\circ} \mathrm{H}^{-}$and $\mathrm{HOO}^{\circ}$ form as a result of reactions of $\mathrm{H}_{2}$ and $\mathrm{O}_{2}$ with the noble metal catalyst. ${ }^{25}$ The hydroxyl radical ( $\mathrm{HO}^{\circ}$ ) is particularly harmful, as it attacks aromatic units with rate constants close to the diffusion limit, i.e. on the order of $10^{9}$ to $10^{10} \mathrm{M}^{-1} \mathrm{~s}^{-1}$. ${ }^{26}$ In contrast, in PFSA ionomers $\mathrm{HO}^{\circ}$ attack is three to four orders of magnitude slower $\left(\sim 10^{6} \mathrm{M}^{-1} \mathrm{~s}^{-127}\right)$ and limited to weak links in the chain. In fact, in a PEFC with PFSA membrane, most of the hydroxyl radicals are 


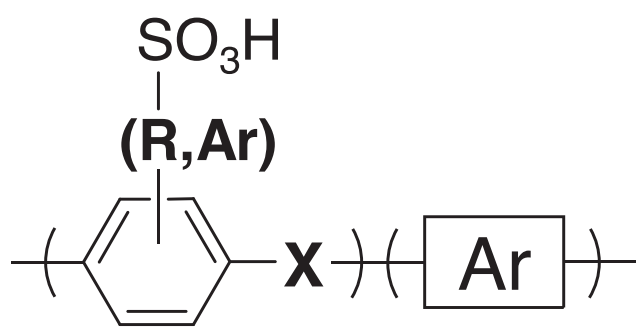

Scheme 1. Schematic structure of sulfonated hydrocarbon-based ionomer. X is a linking group (e.g., sulfone) or a bond.

expected to react with dissolved $\mathrm{H}_{2}$ to form $\mathrm{H}$ which in turn react with $\mathrm{O}_{2}$ to produce $\mathrm{HOO}$, which is much less detrimental than $\mathrm{HO}^{28}$ The resulting average lifetime of HO in PFSA ionomers is in the range of microseconds. This, therefore, allows for effective scavenging of $\mathrm{HO}^{\circ}$ by transition metals, such as cerium-ions and oxides thereof, at concentrations in the range of 0.01 to $0.1 \mathrm{M}^{29} \mathrm{~A}$ key feature of $\mathrm{HO}^{\prime}$ scavenging in PFSA ionomers by cerium-ions is the catalytic mechanism. This is a consequence of redox cycling between $\mathrm{Ce}$ (III) and $\mathrm{Ce}(\mathrm{IV})$ : upon scavenging of $\mathrm{HO}$ by $\mathrm{Ce}(\mathrm{III}), \mathrm{Ce}$ (IV) is formed. $\mathrm{Ce}(\mathrm{IV})$ reacts with $\mathrm{H}_{2} \mathrm{O}_{2}$, which is present in the fuel cell, and regenerates $\mathrm{Ce}(\mathrm{III}){ }^{30}$ The known sources of $\mathrm{H}_{2} \mathrm{O}_{2}$ in the PEFC are two-electron reduction of oxygen to hydrogen peroxide and reaction of $\mathrm{O}_{2}$ crossed-over from the cathode with hydrogen adsorbed on the Pt catalyst. ${ }^{25}$ Hydrocarbon ionomers react much faster with $\mathrm{HO}$ radicals than PFSA ionomers: almost all of the hydroxyl radicals formed will react with the aromatic units of the polymer. The estimated lifetime of $\mathrm{HO}^{\circ}$ is three orders of magnitude lower than in a PFSA ionomer, i.e. around $1 \mathrm{~ns}$, which prevents effective scavenging by cerium-ions at practical concentrations. ${ }^{28}$ Under these circumstances, and in analogy to biology, antioxidant action cannot be based on damage prevention but must focus instead on repair and inhibition of damage propagation. ${ }^{31}$ This may be possible if intermediates formed upon radical attack are sufficiently long-lived. ${ }^{23}$

\section{Radical Attack and Chemical Degradation Mechanism}

The attack by $\mathrm{HO}^{\circ}$ on aromatic units of a polymer $\mathrm{P}$, the followup reactions, and the fate of the compound are described by a generic mechanism (Scheme 2). Evidently, the exact mechanism and kinetics depend on many variables, such as the chemistry of the aromatic units, the type of linking groups, substituent pattern, steric effects, temperature, oxygen concentration, etc. Initially, the $\mathrm{HO}$ reacts with the aromatic group, reaction (1), predominantly by addition, yielding the $\mathrm{OH}$-adduct, i.e. a cyclohexydienyl radical, $\mathrm{P}-\mathrm{OH}$. The rate of reaction between $\mathrm{HO}$ ' and most aromatic compounds is (close to) diffusion controlled and, thus, does not vary significantly with different substituents. ${ }^{32}$ Subsequently, irreversible damage can be inflicted on the polymer according to Path A degradation, reaction (2). This can occur, for example, through hydroxylation via addition of $\mathrm{O}_{2}$ and elimination of $\mathrm{HOO} .{ }^{33}$ The formed phenol is oxidized more easily than the parent compound. This can lead to accelerated permanent damage by successive oxidative reactions, ring opening or by crosslinking intermediates via Michael-addition. ${ }^{34}$ Additional crosslinking reactions can occur through recombination of different radical centres (intra-chain or inter-chain). The observed embrittlement of hydrocarbon membranes in the fuel cell over time is consistent with this mechanism of crosslink formation and stiffening of the polymer. ${ }^{16}$

At sufficiently low $\mathrm{pH}, \mathrm{P}-\mathrm{OH}$ will undergo acid promoted water elimination, reaction (3), to form the cation radical $\mathrm{P}^{++35}$ From this intermediate a number of harmful reactions are conceivable (degradation Path B, reaction (4)) such as chain scission and, if the aromatic ring is sulfonated, desulfonation. ${ }^{36}$ Cation radicals are strongly electron withdrawing. The protons of the $\mathrm{C}-\mathrm{H}$ bonds in $\alpha$-position to aromatic cation radicals are, therefore, acidified and

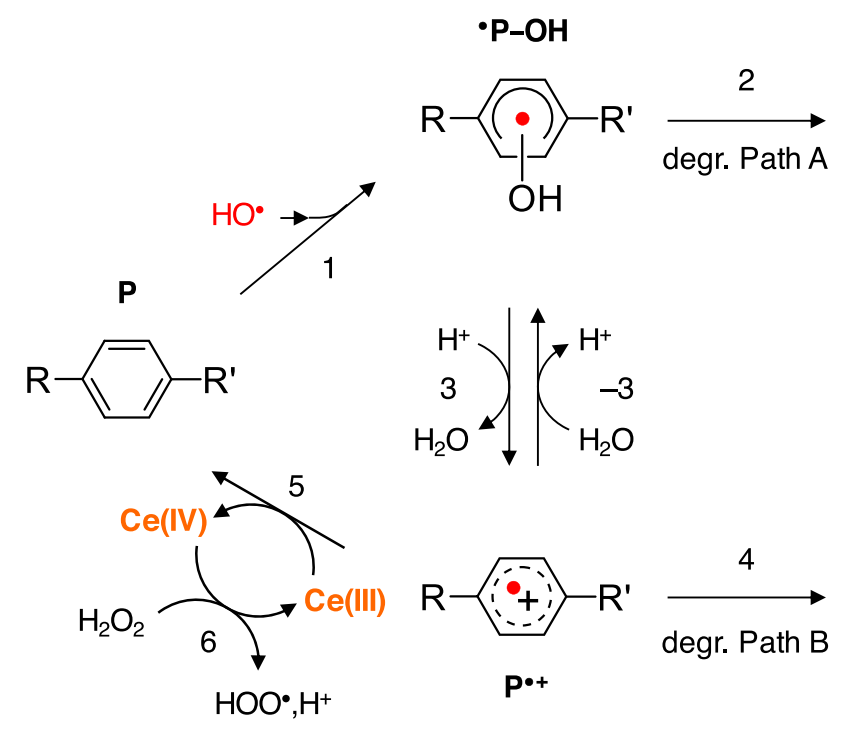

Scheme 2. Simplified reaction pathway of aromatic compounds considered in this study. Attack by $\mathrm{HO}^{\prime}$ forming the $\mathrm{OH}$-adduct, $\mathrm{P}-\mathrm{OH}$ (reaction 1), which can undergo irreversible degradation (reaction 2) or acid promoted water elimination to form the cation radical, $\mathrm{P}^{++}$(reaction 3). The backward reaction is reaction-3. $\mathrm{P}^{+}$can undergo irreversible degradation (reaction 4 ) or a reduction reaction with $\mathrm{Ce}(\mathrm{III})$ (reaction 5), which repairs the aromatic unit to the starting compound. The produced $\mathrm{Ce}(\mathrm{IV})$ reacts with $\mathrm{H}_{2} \mathrm{O}_{2}$ to restore $\mathrm{Ce}(\mathrm{III})$ (reaction 6).

deprotonate readily to form benzyl radicals. ${ }^{37}$ Another important reaction to consider is the nucleophilic addition of water to $\mathrm{P}^{++}$, reaction $(-3)$, the rate of which strongly depends on the substituent pattern of the ring. ${ }^{38}$ The ultimate fate of the polymer, therefore, strongly depends on the equilibrium between the $\mathrm{OH}$-adduct and the cation radical, given by the reactions 3 and -3 , and the rate of path $A$ and path $\mathrm{B}$ degradation reactions.

Recently, we have shown that $\mathrm{Ce}(\mathrm{III})$ can react with "aromatic cation radicals" and thereby potentially act as repair agent in sulfonated hydrocarbon-based ionomers, reaction (5). ${ }^{39}$ In this article, we extend the study to elevated temperatures relevant for fuel cell application $\left(\sim 80^{\circ} \mathrm{C}\right)$.

$$
\mathrm{P}^{++}+\mathrm{Ce}(\mathrm{III}) \rightarrow \mathrm{P}+\mathrm{Ce}(\mathrm{IV})
$$

If sufficiently fast, reaction (5) prevents irreversible damage to both the cyclohexadienyl and the cation radicals, reactions (2) and (4). Essentially, the effectiveness of this antioxidant strategy depends on the concentration of $\mathrm{Ce}(\mathrm{III})$ as the "repair agent" and the rate constant of reaction (5), $k_{5}$, in relation to the rate constants associated with reactions (2) and (4). Additionally, we study the kinetics of the regeneration reaction of $\mathrm{Ce}(\mathrm{III})$, reaction (6), also as a function of temperature.

$$
\mathrm{Ce}(\mathrm{IV})+\mathrm{H}_{2} \mathrm{O}_{2} \rightarrow \mathrm{Ce}(\mathrm{III})+\mathrm{H}^{+}+\mathrm{HOO}^{\circ}
$$

Conceptually, the combination of reactions (5) and (6) enables a catalytic repair mechanism of the hydrocarbon ionomer in the fuel cell, Scheme 2. The standard reduction potential of the cerium couple is $E^{\circ}(\mathrm{Ce}(\mathrm{IV}) / \mathrm{Ce}(\mathrm{III}))=1.44 \mathrm{~V}^{40}$ The potential $E^{\circ}\left(\mathrm{P}^{+} / \mathrm{P}\right)$ is in the range of $2.0-2.4 \mathrm{~V}$ for an aromatic ring with intermediate electron density. ${ }^{32}$ The efficacy of the repair reaction also depends on the concentration ratio of $\mathrm{Ce}$ (III) to $\mathrm{Ce}$ (IV) under steady-state conditions. This will be estimated in the kinetic simulation section. The half-cell reaction $\mathrm{HOO}^{\circ}+\mathrm{H}^{+}+\mathrm{e}^{-} \rightarrow \mathrm{H}_{2} \mathrm{O}_{2}$ has a standard electrode potential of $E^{\circ}\left(\mathrm{HOO}, \mathrm{H}^{+} / \mathrm{H}_{2} \mathrm{O}_{2}\right)=1.46 \mathrm{~V}$ at $\mathrm{pH} 0 .{ }^{41}$ Therefore, the repair reaction (5) and the regeneration reaction (6) should be thermodynamically favorable. 
We use a poly $(\alpha$-methylstyrene sulfonate) (PAMSS) oligomer as a hydrocarbon ionomer model compound in this study. It is a continuation of our earlier work on the effects of radical attack on styrene based oligomers. ${ }^{33,36,39,42} \mathrm{We}$ anticipate that the results obtained largely characterize the generic behaviour of hydrocarbon ionomers. Conceptually, we analyze how modifications to the polymer chemistry can influence the degradation behavior. Experimental work is combined with modelling in order to explore the prospect of mitigating radical induced degradation of polymers containing aromatic units through repair of the cation radical intermediate. With this approach we hope to gain a basis for improvements of membranes to be tested on the device level.

\section{Methods-Experimental}

Many of the reactions measured and discussed are of second order but, under our conditions, pseudo-first order. With reaction (3) as example, we use the following notation: $k_{3}{ }^{\prime}=k_{3} \cdot\left[\mathrm{H}^{+}\right], k_{-3}{ }^{\prime}=$ $k_{-3} \cdot\left[\mathrm{H}_{2} \mathrm{O}\right]$, with $k_{3}$ and $k_{-3}$ the "real" forward and backward rate constants, $k_{3}{ }^{\prime}$ and $k_{-3}{ }^{\prime}$ the pseudo-first order rate constants at the given conditions (here $\mathrm{pH}$ and water concentration), $K_{3}=k_{3} / k_{-3}$ the equilibrium constant and $K_{3}{ }^{\prime}=k_{3}{ }^{\prime} / k_{-3}{ }^{\prime}$ the position of the equilibrium under the given conditions. All errors given represent standard deviations, not confidence intervals. The suppliers and purity of the chemicals used are given in the Supporting Information, section 1 .

Kinetics measurements.-In order to measure $k_{5}$, the unstable cation radical $\mathrm{P}^{++}$has to be produced in high enough concentrations that its reaction can be followed with time-resolution in the microsecond range. To achieve this, we applied the pulse-radiolysis technique using the setup at ETH: ${ }^{43}$ samples are exposed to short pulses of ionizing radiation, here fast electrons, to ionize material. The setup is similar to laser flash photolysis. Instead of a pulse of light (2-6 eV photon energy), a pulse of high-energy radiation $(2 \mathrm{MeV})$ is applied. ${ }^{44}$ In liquids, ionization will eventually form solvated electrons and products of the initially formed cation radicals. Ionization occurs in mass-proportional manner and in dilute solution, therefore, initially only solvent radicals and electrons are formed. Product concentrations are proportional to the applied dose and known for water. ${ }^{45}$ We used an oligomer of PAMSS for our studies. The oligomer had a mass average molecular weight of 14 ' $600 \mathrm{Da}$, a polydispersity index of $<1.06$, and a degree of sulfonation of $>95 \%$ (PSS Polymer Standards Service, Mainz, Germany). This corresponds to a degree of polymerization of around 60.

The radicals $\mathrm{SO}_{4}{ }^{-}$and $\mathrm{HO}^{\circ}$ were used to oxidize PAMSS, reactions (7) and (1).

$$
\mathrm{P}+\mathrm{SO}_{4}^{\cdot-} \rightarrow \mathrm{P}^{\cdot+}+\mathrm{SO}_{4}{ }^{2-}
$$

The rate constant of reaction (6) was measured by mixing $\mathrm{H}_{2} \mathrm{O}_{2}$ and $\mathrm{Ce}(\mathrm{IV})$ under pseudo first-order conditions in an Applied Photophysics SX18 stopped-flow apparatus (Leatherhead, UK). In stopped-flow the content of two syringes are forced by high pressure through a mixer coupled to a measurement cell and subsequently into a product syringe. The mixing is stopped when the product syringe hits a stop-block, and this is "time zero." The reaction is then followed in time resolved manner, usually by absorption spectroscopy. ${ }^{46}$ When Ce(IV) was used in excess, five single traces were acquired per reaction condition and subsequently evaluated separately (Appendix B and SI). In the controls $\left(\mathrm{H}_{2} \mathrm{O}_{2}\right.$ in excess), five single traces were averaged per reaction condition. The averages were then analyzed using a first-order decay model to obtain the observed pseudo-first order rate constant $k_{6, \text { obs }}$.

Importantly, peroxide solutions become increasingly unstable at elevated temperatures, which limits the measurement range and the accuracy of data at temperatures above $60^{\circ} \mathrm{C}$ in certain experiments. This is true for both pulse radiolysis and stopped flow experiments. The experimental conditions suffer additional constraints and are, therefore, a result of optimization and compromise, Appendix A. Please see Appendices A and B also for more details on the pulse radiolysis and stopped flow experiments, respectively.

\section{Methods-Kinetics Model}

Our simplified kinetics model describes the main reaction pathways initiated by the reaction of $\mathrm{HO}^{\circ}$ with the polymer, based on our earlier work. $^{25,29}$ In analogy to our recent conference proceedings, ${ }^{47}$ we assume a constant rate of radical formation and their attack of the polymer, reaction (1), which describes the constant bombardment of the membrane by $\mathrm{HO}^{\circ}$ in an operating fuel cell. We use a value of $r_{\mathrm{HO}} \cdot=$ $10^{-6} \mathrm{Ms}^{-1}$ here, cf. Supporting Information for explanations how this value was obtained. However, the qualitative outcome of the model does not depend on the initial rate of attack of the polymer, because we are looking at the probability of certain degradation pathways and relative changes compared to a scenario without antioxidants. By extension, the actual membrane lifetime in the fuel cell is not of primary interest, but rather the relative lifetime improvement.

We assume that the attack of the polymer $\mathrm{P}$ by HO leads to the formation of intermediates $\mathrm{P}^{*}$, which then undergo further reactions. We describe the degradation by a "lumped" effective first-order rate constant $k_{\text {eff }}$, which embodies a combination of different reactions, as indicated in Scheme 2 and reaction (8).

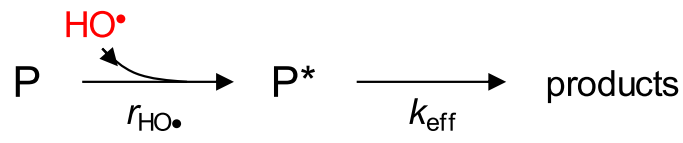

In the simulation we assume a steady state, i.e., a constant concentration of intermediates [ $\left.\mathrm{P}^{*}\right]$ with equal rates of formation $r_{\mathrm{HO}} \cdot$ and decay $k_{\mathrm{eff}} \cdot\left[\mathrm{P}^{*}\right]$. The detailed analysis of the kinetic scheme and derivation of expressions given in this section can be found in Appendix C. The parameter values used in the simulation are listed in Table I.

Under the conditions of this study $[\mathrm{Ce}(\mathrm{III})] \approx[\mathrm{Ce}]$ (see Results). In order to quantify the efficacy of repair reaction (5) compared to Path B degradation, reaction (4), we define the mitigation factor $\mu_{\mathrm{B}}$ of degradation Path B. This is in analogy to our earlier conceptual study.

$$
\mu_{\mathrm{B}}=1+\frac{k_{5}[\mathrm{Ce}]}{k_{4}}
$$

This describes the factor by which the lifetime of the polymer is expected to be improved if damage would occur only via Path B.

\begin{tabular}{|c|c|c|}
\hline Parameter & Value & Description \\
\hline$r_{\mathrm{HO}}$ & $10^{-6} \mathrm{M} \cdot \mathrm{s}^{-1}$ & formation rate of $\mathrm{HO}^{\circ}$ and rate of polymer attack \\
\hline$[\mathrm{P}]$ & $10 \mathrm{M}$ & concentration of aromatic units in hydrocarbon membrane ${ }^{a}$ \\
\hline$\left[\mathrm{P}_{-} \mathrm{SO}_{3}{ }^{-}\right]=\left[\mathrm{H}^{+}\right]$ & $1.5 \mathrm{M}$ & density of sulfonic acid groups ${ }^{\text {a) }}$ \\
\hline$\left[\mathrm{H}_{2} \mathrm{O}_{2}\right]$ & $5 \cdot 10^{-4} \mathrm{M}$ & background concentration of hydrogen peroxide ${ }^{\text {b) }}$ \\
\hline
\end{tabular}

Table I. Model parameters used in the simulation.

a) cf. Supporting Information, section 6 for details. b) cf. Ref. 25 . 


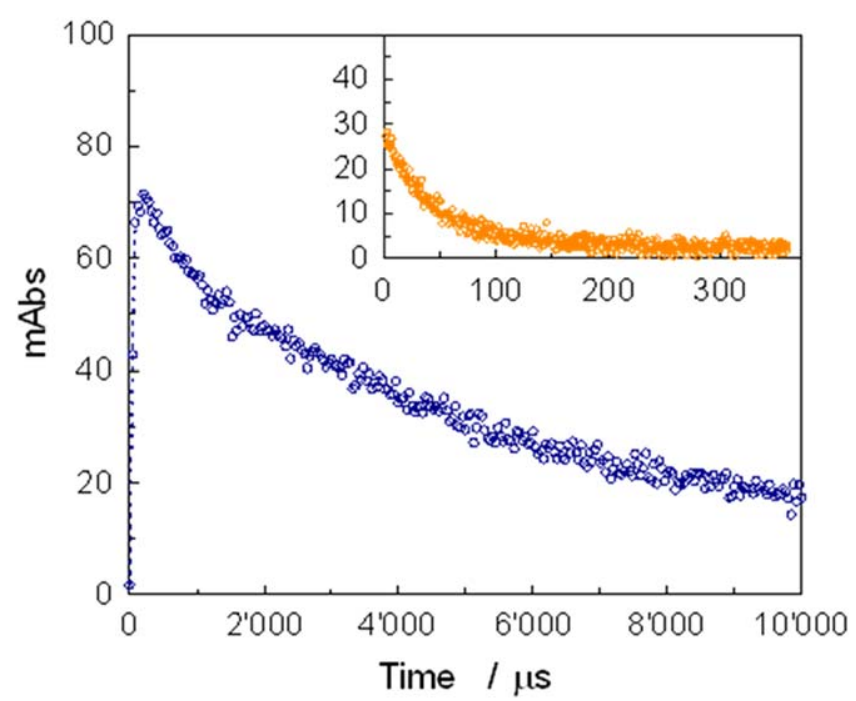

Figure 1. Effect of Ce(III) on the decay of $\mathrm{P}^{++}$: change of optical density in the absence and in the presence (inset) of $0.2 \mathrm{mM} \mathrm{Ce}(\mathrm{III})$ at $560 \mathrm{~nm}$ after pulse irradiation of argon saturated $10 \mathrm{mM} \mathrm{K}_{2} \mathrm{~S}_{2} \mathrm{O}_{8}$ solutions that contained $0.1 \mathrm{mM}$ PAMSS and $1 \mathrm{mM} \mathrm{H}_{2} \mathrm{SO}_{4}$. Doses of $21 \mathrm{~Gy}$ (main figure) and $37 \mathrm{~Gy}$ (inset) were applied. The timescale of the absorbance decay differs by approximately 2 orders of magnitude. $\mathrm{Ce}$ (III) accelerates the observed decay.

Overall, degradation Path A must also be considered. The analysis of the kinetic framework (see Appendix C), considering both degradation pathways, yields the total mitigation factor $\mu_{\mathrm{A}+\mathrm{B}}$,

$$
\mu_{\mathrm{A}+\mathrm{B}}=1+\frac{k_{5}[\mathrm{Ce}]}{k_{2} / K_{3}^{\prime}+k_{4}}=1+f_{\mathrm{B}} \frac{k_{5}[\mathrm{Ce}]}{k_{4}}
$$

$K_{3}{ }^{\prime}$ characterizes the position of the equilibrium between the $\mathrm{OH}-$ adduct, $\mathrm{P}-\mathrm{OH}$, and the cation radical, $\mathrm{P}^{+}$(cf. MethodsExperimental). For large values of $\mu_{\mathrm{B}}$ and $\mu_{\mathrm{A}+\mathrm{B}} \gg 1$, the two mitigation factors differ by a factor $f_{\mathrm{B}}$, the fraction of Path $\mathrm{B}$ degradation.

\section{Results}

The results of the pulse radiolysis study on PAMSS are presented first. Rate constants for the repair reaction (5) and the pseudo firstorder rate constant for degradation along Path B, reaction (4) (Scheme 2), were determined. Then, stopped-flow results on reaction (6) are described. Subsequently, these data are used together with literature data to explore the prospects and limitations of polymer repair in a hydrocarbon fuel cell membrane doped with cerium-ions.

Kinetics measurements.-When a deaerated (Ar saturated) solution of $0.1 \mathrm{mM}$ PAMSS, $10 \mathrm{mM} \mathrm{K}_{2} \mathrm{~S}_{2} \mathrm{O}_{8}$ and $1 \mathrm{mM} \mathrm{H}_{2} \mathrm{SO}_{4}$ is pulse-irradiated with a dose of $30 \mathrm{~Gy}$, we expect the formation of approximately $6 \mu \mathrm{M} \mathrm{SO}_{4}{ }^{-}$. These in turn oxidize the polymer to form $\mathrm{P}^{+}$, reaction (7), which can be observed by a corresponding absorption build-up at $560 \mathrm{~nm} .{ }^{36}$ Water radiolysis results in direct formation of $8 \mu \mathrm{M} \mathrm{HO}$ that reacts with PAMSS to produce $\mathrm{P}-\mathrm{OH}$, reaction (1). We observed a decay of the $560 \mathrm{~nm}$ band over several

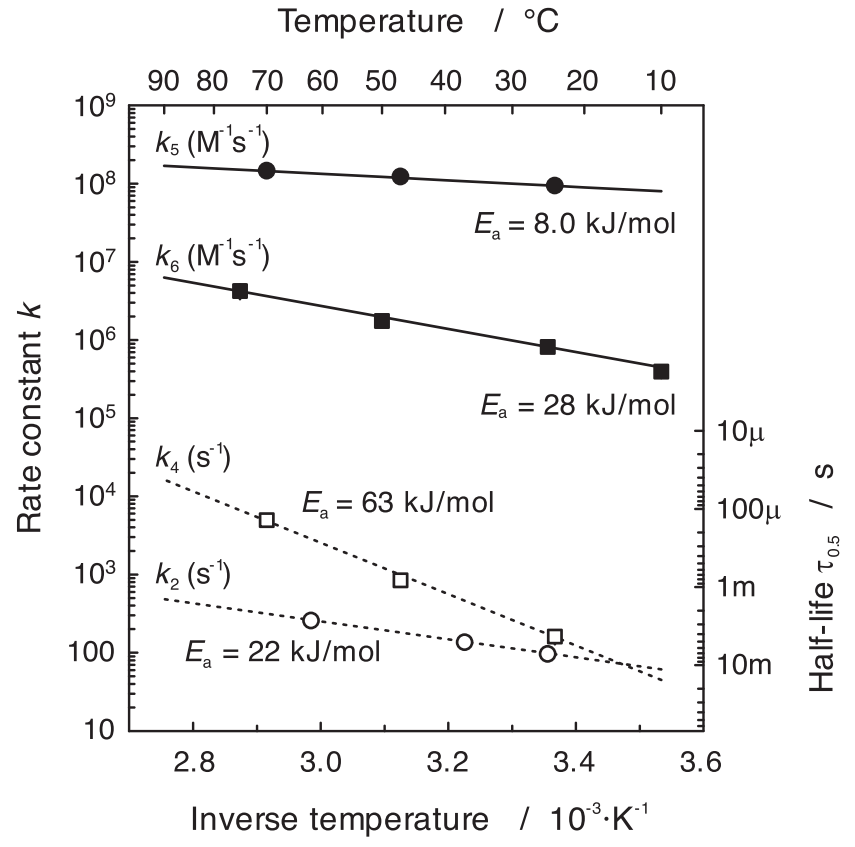

Figure 2. Overview of rate constants, represented in an Arrhenius plot, and the activation energies $E_{\mathrm{a}}$, obtained by linear regression analysis. The values for $k_{5}$ and $k_{6}$ (full symbols) represent measurements, the ones for $k_{2}$ and $k_{4}$ (open symbols) are mathematical place holders in the model (see text). The half-life of intermediates in the absence of cerium is calculated as $\tau_{0.5}=$ $\ln (2) / k_{2,4}$.

milliseconds, Fig. 1, which is tentatively attributed to fragmentation reactions according to Path $\mathrm{B}$, Scheme 2 . If $0.2 \mathrm{mM} \mathrm{Ce(III)} \mathrm{was}$ added to the solutions, the observed maximum absorption decreased because of the competition between PAMSS and Ce(III) for the oxidant radicals, $\mathrm{HO}^{-}$and $\mathrm{SO}_{4}{ }^{-}$. Importantly, in the presence of $0.2 \mathrm{mM} \mathrm{Ce}(\mathrm{III})$ the observed decay rate of the polymer intermediate increased by two orders of magnitude, which is visible in the drastically reduced half-life, inset of Fig. 1 (see also Figs. S1 and S2 (available online at stacks.iop.org/JES/168/054514/mmedia)). This effect is interpreted in terms of reaction (5).

In order to establish the rate constants and the activation energy of reaction (5), solutions with $0.1,0.3$ and $1 \mathrm{mM} \mathrm{Ce}_{2}\left(\mathrm{SO}_{4}\right)_{3}$ and 0.1 , 0.3 and $1 \mathrm{mM}$ PAMSS, respectively, were pulse-irradiated; $k_{5, \mathrm{obs}}$ was derived from the slope of the plot $k_{\mathrm{obs}}$ vs [Ce(III)], with $k_{\mathrm{obs}}$ being the pseudo first-order rate constant associated with the observed absorption decay at $560 \mathrm{~nm}$ (Fig. S3). Measurements were repeated at different temperatures, Table II. At high enough [Ce(III)], reaction (5) outcompetes Path A and Path B. But even then the observed decay, i.e. reaction $(5$, obs), is influenced by preequilibrium (3), Scheme 2. Briefly, $k_{5, \mathrm{obs}}$, is a function of $K_{3}$ (Appendix A) and represents a low limit of the real value, $k_{5}$. Therefore, also the slope of the plot $\ln \left(k_{5, \mathrm{obs}}\right) \cdot \mathrm{R}$ vs $1 / T$, Fig. S5, represents the activation energy of the overall reaction. We derive an overall activation energy of $E_{\mathrm{a}, 5 \mathrm{obs}}=9 \pm 2 \mathrm{~kJ} \mathrm{~mol}^{-1}$ if all individual measurements are used for its calculation. If $E_{\mathrm{a}, 5 \mathrm{obs}}$ is derived from the averages of the measurements at each given temperature, we find

Table II. Rate constants measured at different temperatures.

\begin{tabular}{lcccc} 
Temperature & $k_{5, \mathrm{obs}}$ & $k_{\text {PathB }}$ & Temperature \\
\hline$\left({ }^{\circ} \mathrm{C}\right)$ & $\left(10^{7} \mathrm{M}^{-1} \mathrm{~s}^{-1}\right)$ & $\left(10^{2} \mathrm{M}^{-1} \mathrm{~s}^{-1}\right)$ & ${ }^{\circ} \mathrm{C}$ & $\left(10^{5} \mathrm{M}^{-1} \mathrm{~s}^{-1}\right)$ \\
24 & $9.4 \pm 0.2$ & $1.6 \pm 0.3$ & 10 & $4.0 \pm 0.7$ \\
47 & $12 \pm 0.3$ & $8 \pm 1$ & 25 & $8.0 \pm 0.1$ \\
70 & $15 \pm 0.5$ & $49 \pm 2$ & 50 & $18 \pm 2$ \\
& & & 74
\end{tabular}


$E_{\mathrm{a}, 5 \mathrm{obs}}=8 \pm 1 \mathrm{~kJ} \mathrm{~mol}^{-1}$, the value displayed in Fig. 2. For the calculation of repair efficacy, the latter value represents the conservative low limit and is therefore used.

In principle, the intercept in a plot of $k_{\mathrm{obs}}$ vs [Ce(III)] represents the rate constant for Path $\mathrm{B}$ degradation. However, the associated uncertainty precludes such determination of $k_{\mathrm{PathB}}$. An independent determination of $k_{\mathrm{PathB}}$ was carried out by pulse irradiation of $0.1 \mathrm{mM}$ PAMSS in the absence of cerium (Fig. S2). For Path B we find $E_{\mathrm{a}, \text { PathB }}=63 \pm 2 \mathrm{~kJ} \mathrm{~mol}^{-1}$ (cf. Appendix A and Fig. S5).

The rate constant $k_{6}$ was measured by stopped-flow: two solutions, one containing $\mathrm{Ce}(\mathrm{IV})$ and one containing $\mathrm{H}_{2} \mathrm{O}_{2}$, were mixed and the decay of $\mathrm{Ce}(\mathrm{IV})$ was followed by absorption spectroscopy at $320 \mathrm{~nm}$ (Fig. S10). The measurements were carried out at $\mathrm{pH} 1\left(100 \mathrm{mM} \mathrm{H}_{2} \mathrm{SO}_{4}\right)$ under pseudo first-order conditions (see Appendix $\mathrm{B}$ for details). With $\mathrm{Ce}(\mathrm{IV}): \mathrm{H}_{2} \mathrm{O}_{2} \approx 10$ : 1 , and covering a concentration range of one order of magnitude between $30 \mu \mathrm{M}$ and $290 \mu \mathrm{M}$ Ce(IV) (Table B.I), we carried out experiments at $10{ }^{\circ} \mathrm{C}, 25{ }^{\circ} \mathrm{C}, 50{ }^{\circ} \mathrm{C}$ and $74{ }^{\circ} \mathrm{C}$ (Fig. S11). The obtained rate constants are listed in Table II (see also Table B-II). As a control, we used $\mathrm{H}_{2} \mathrm{O}_{2}$ in a tenfold excess with $\left[\mathrm{H}_{2} \mathrm{O}_{2}\right]=1 \mathrm{mM}$ and $0.3 \mathrm{mM}$ (Table SII). The obtained value of $8 \cdot 10^{5} \mathrm{M}^{-1} \mathrm{~s}^{-1}$ at $25^{\circ} \mathrm{C}$ agrees well with the value of $10^{6} \mathrm{M}^{-1} \mathrm{~s}^{-1}$ reported in the literature. ${ }^{48} \mathrm{An}$ Arrhenius-plot of the results, Fig. S12, yields an activation energy for reaction (6) of $E_{\mathrm{a}, 6}=29.2 \pm 1.3 \mathrm{~kJ} \mathrm{~mol}^{-1}$ for the reactions with $\mathrm{Ce}(\mathrm{IV})$ in excess and $E_{\mathrm{a}, 6}=30.7 \pm 0.5 \mathrm{~kJ} \mathrm{~mol}^{-1}$ with $\mathrm{H}_{2} \mathrm{O}_{2}$ in excess, which is identical within the error margin. Note that at $74{ }^{\circ} \mathrm{C}$ we observed decomposition of $\mathrm{H}_{2} \mathrm{O}_{2}$ in the thermostated reactant syringe before mixing. This has no bearing on the derived rate constant if $\mathrm{Ce}(\mathrm{IV})$ is in excess. It becomes detrimental, however, for cases where $\mathrm{H}_{2} \mathrm{O}_{2}$ is in excess and its absolute concentration is part of the pseudo-first order rate constant $k_{6}^{\prime}$. If $\left[\mathrm{H}_{2} \mathrm{O}_{2}\right]$ is overestimated the calculated rate constant is underestimated, $k_{6}=k_{6}^{\prime} /\left[\mathrm{H}_{2} \mathrm{O}_{2}\right]$. The corresponding data, open square in Fig. S12, was not used in our calculations.

Kinetics simulation.-The simulation of the degradation kinetics of the polymer according to Scheme 2 is based on the rate constants listed in Table III, with the model parameters given in Table I.

Our model is a simplification of a complex reaction framework and is used to gain an overview and identify a starting point for improvement strategies. It is known that polymer degradation will take place from the cyclohexadienyl ( $\mathrm{P}-\mathrm{OH}$, Path $\mathrm{A})$ as well as from the cation radical $\left(\mathrm{P}^{+}\right.$, Path $\left.\mathrm{B}\right)$. Exact mechanisms are not known at this point. Modelling, however, requires mathematical values, $k_{2}$ and $k_{4}$, for the calculation. These values describe the stability of the polymer in the absence of additives. The more intuitive radical persistence shows the timescale in which repair reaction (5) has to occur and is given by the half-lives $\tau_{0.5}(\mathrm{P}-\mathrm{OH})=\ln (2) / k_{2}$ and

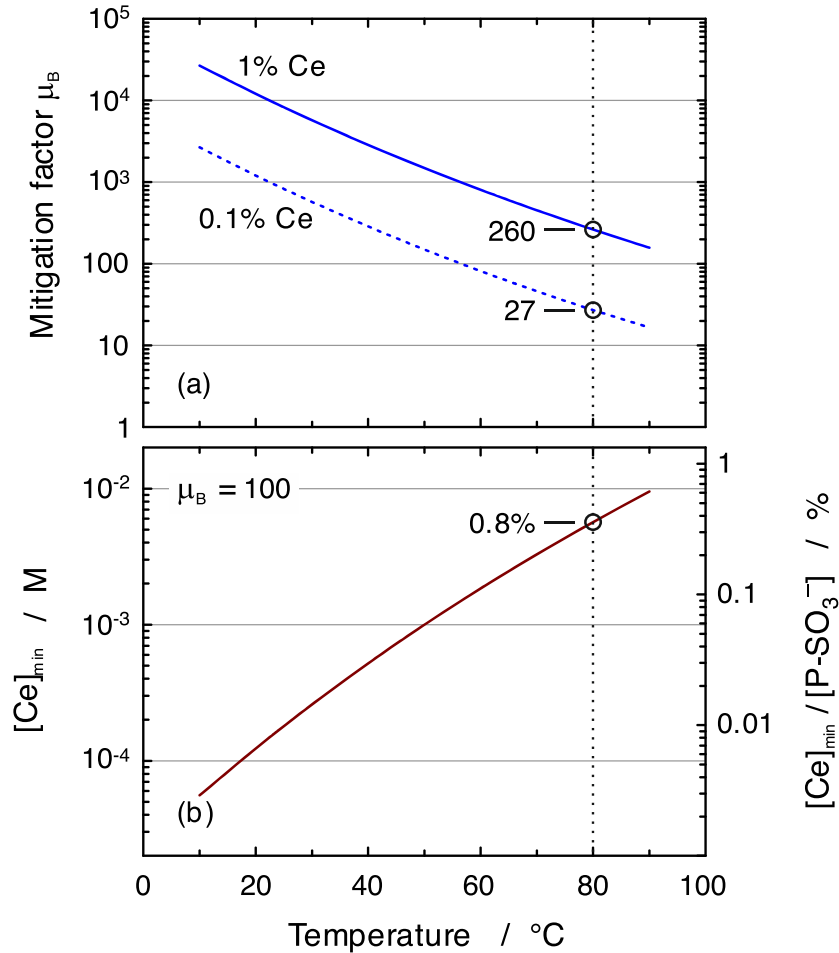

Figure 3. The temperature dependence of the mitigation factor $\mu_{\mathrm{B}}$, which quantifies the reduction of Path $\mathrm{B}$ degradation rate of the cation radical $\mathrm{P}^{+}$. (a) Influence of the cerium-ion doping level, (b) minimum cerium concentration needed to achieve $\mu_{\mathrm{B}}=100$. Values at $80{ }^{\circ} \mathrm{C}$ are highlighted, as this is a typical fuel cell operating temperature.

$\tau_{0.5}\left(\mathrm{P}^{+}\right)=\ln (2) / k_{4}$ (Fig. 2, right axis). We derive estimates of these values from data published or measured here.

The concentration ratio of the two cerium oxidation states can be obtained from the steady state of reactions (5) and (6):

$$
\frac{[\mathrm{Ce}(\mathrm{IV})]}{[\mathrm{Ce}(\mathrm{III})]}=\frac{k_{5}}{k_{6}} \cdot \frac{\left[\mathrm{P}^{++}\right]}{\left[\mathrm{H}_{2} \mathrm{O}_{2}\right]}
$$

The cation radical concentration $\left[\mathrm{P}^{+}\right]$is maximal if $K_{3}^{\prime} \gg 1$, hence $[\mathrm{P}-\mathrm{OH}] \ll\left[\mathrm{P}^{+}\right]$. According to reaction $(8)$ this means $\left[\mathrm{P}^{*}\right]=\left[\mathrm{P}^{+}\right]$ and assuming $k_{5}[\mathrm{Ce}] \ll k_{4}$ we write $k_{\text {eff }}=k_{4}$ and obtain $\left[\mathrm{P}^{++}\right]=$ $r_{\mathrm{HO}} / \mathrm{k}_{4}$. Equation 11 therefore predicts that $[\mathrm{Ce}(\mathrm{IV})]$ is well below $1 \%$ of the total cerium concentration under the conditions used $\left(r_{\mathrm{HO}}=10^{-6} \mathrm{M} \mathrm{s}^{-1},\left[\mathrm{H}_{2} \mathrm{O}_{2}\right]=5 \cdot 10^{-4} \mathrm{M}\right)$. In a worst-case scenario, if

Table III. Reactions considered in the kinetic simulation and corresponding rate constants used.

\begin{tabular}{|c|c|c|c|c|c|}
\hline \multirow{2}{*}{ \# } & \multirow{2}{*}{ Reaction } & \multicolumn{3}{|c|}{ Rate constant } & \multirow{2}{*}{ References } \\
\hline & & $25^{\circ} \mathrm{C}$ & $80^{\circ} \mathrm{C}$ & Unit & \\
\hline 1 & $\mathrm{P}+\mathrm{OH} \rightarrow \mathrm{P}-\mathrm{OH}$ & \multicolumn{4}{|c|}{ assume constant $r_{\mathrm{HO}}=10^{-6} \mathrm{Ms}^{-1}$} \\
\hline 2 & & $\left.1.4 \cdot 10^{4} \mathrm{~b}\right)$ & $5.6 \cdot 10^{4}$ b) & $\mathrm{s}^{-1}$ & 33 \\
\hline 3 & $\mathrm{P}-\mathrm{OH}+\mathrm{H}^{+} \rightarrow \mathrm{P}^{+}+\mathrm{H}_{2} \mathrm{O}$ & $1.5 \cdot 10^{9}$ & $>1.5 \cdot 10^{9 \mathrm{c})}$ & $\mathrm{M}^{-1} \mathrm{~s}^{-1}$ & 38 \\
\hline-3 & $\mathrm{P}^{+}+\mathrm{H}_{2} \mathrm{O} \rightarrow \mathrm{P}-\mathrm{OH}+\mathrm{H}^{+}$ & $2 \cdot 10^{7}$ & $>2 \cdot 10^{7}$ & $\mathrm{M}^{-1} \mathrm{~s}^{-1}$ & 38 \\
\hline 6 & $\mathrm{Ce}^{4+}+\mathrm{H}_{2} \mathrm{O}_{2} \rightarrow \mathrm{Ce}^{3+}+\mathrm{H}^{+}+\mathrm{HOO}$ & $8.2 \cdot 10^{5}$ & $4.8 \cdot 10^{6 \mathrm{f}}$ & $\mathrm{M}^{-1} \mathrm{~s}^{-1}$ & This work \\
\hline
\end{tabular}

a) Decay in the absence of oxygen, $E_{\mathrm{a}}=22 \mathrm{~kJ} \mathrm{~mol}^{-1}$ (Fig. 2), see also Figs. S4 and S5. b) Effective first-order rate constant $\left(\mathrm{O}_{2}\right.$ degradation pathway) at $25^{\circ} \mathrm{C}$, cf. Appendix D. This value is used in the simulation. The value at $80^{\circ} \mathrm{C}$ was calculated assuming an activation energy of $22 \mathrm{~kJ} \mathrm{~mol}^{-1}$. c) For anisole at $\mathrm{pH}<3$ the $\mathrm{OH}$ addition reaction becomes rate determining and not the reaction with protons, i.e. the protonation is (almost) diffusion controlled. ${ }^{49}$ d) Extrapolated using $E_{\mathrm{a}}=63 \mathrm{~kJ} \mathrm{~mol}^{-1}$ (Fig. 2). e) Extrapolated using $E_{\mathrm{a}}=8.0 \mathrm{~kJ} \mathrm{~mol}^{-1}$ (Fig. 2). f) Extrapolated using $E_{\mathrm{a}}=28.2 \mathrm{~kJ} \mathrm{~mol}{ }^{-1}$ (Fig. 2). 


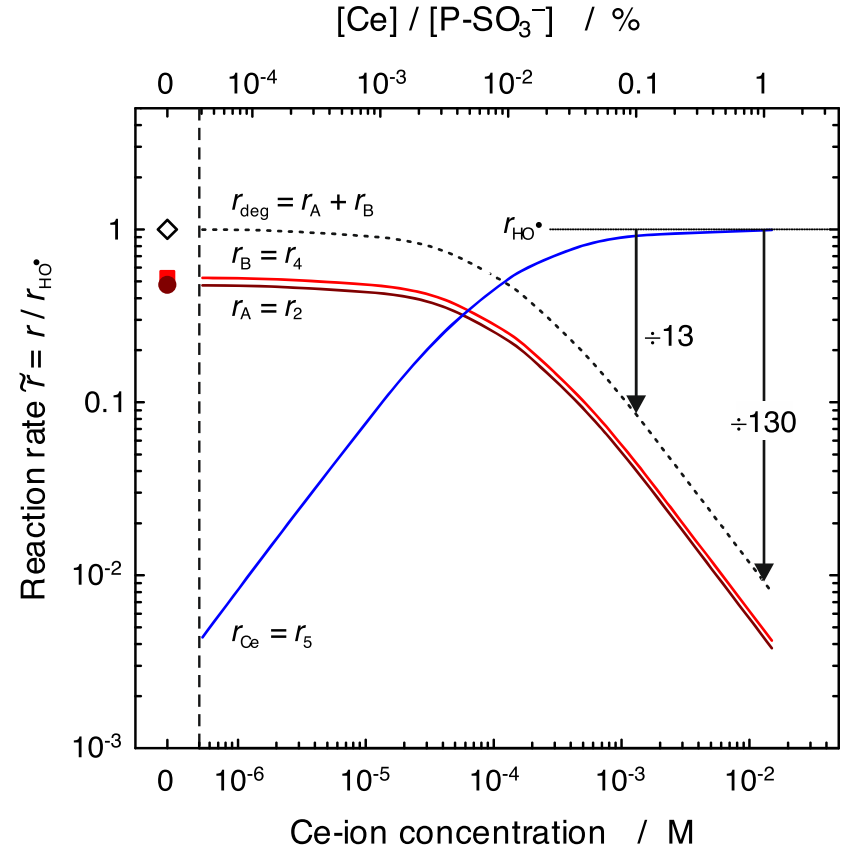

Figure 4. Calculated damage rates and repair rate $\tilde{r}$ normalized to the rate of attack, $r_{\mathrm{HO}}$, at a temperature of $80{ }^{\circ} \mathrm{C}$ as a function of cerium-ion concentration in the membrane. $r_{\mathrm{A}}$ and $r_{\mathrm{B}}$ represent degradation pathways $\mathrm{A}$ and $\mathrm{B}$, respectively, and $r_{\mathrm{A}+\mathrm{B}}$ the sum of $\mathrm{A}$ and $\mathrm{B} . r_{\mathrm{Ce}}$ represents the repair reaction (5). The arrows and values at 0.1 and $1 \% \mathrm{Ce}$ indicate the total mitigation factor $\mu_{\mathrm{A}+\mathrm{B}}$.

$r_{\mathrm{HO}}$ is increased by a factor of ten $\left(10^{-5} \mathrm{M} \mathrm{s}^{-1}\right)$ and $\left[\mathrm{H}_{2} \mathrm{O}_{2}\right]$ is decreased by a factor of ten $\left(5 \cdot 10^{-5} \mathrm{M}\right),[\mathrm{Ce}(\mathrm{IV})]$ is still less than $1 \%$ of the total cerium content. Mathematically, $[\mathrm{Ce}(\mathrm{III})] \approx[\mathrm{Ce}(\mathrm{III})]+$ $[\mathrm{Ce}(\mathrm{IV})]=[\mathrm{Ce}]$, even at elevated temperatures, and repair reaction (5) is always at its maximum efficacy.

The efficacy of the repair of $\mathrm{P}^{+}$, reaction (5), is in competition with degradation Path B (Scheme 2 and Table III). In analogy to PFSA membranes, ${ }^{30}$ we considered $1 \%$ cerium ions relative to the concentration of membrane sulfonate groups, $\left[\mathrm{P}-\mathrm{SO}_{3}{ }^{-}\right]$, to be the upper concentration limit in a PEM for fuel cells. Based on Eq. 9, Fig. 3a shows the mitigation factor $\mu_{\mathrm{B}}$ for Path $\mathrm{B}$ degradation as a function of temperature for $0.1 \%$ and $1 \%[\mathrm{Ce}] /\left[\mathrm{P}_{-} \mathrm{SO}_{3}{ }^{-}\right]$. The ratio $\mathrm{k}_{5} / \mathrm{k}_{4}$ decreases with increasing temperature because of the different activation energies of reaction (4) and reaction (5), Fig. 2. In other words, high fuel cell temperatures reduce the repair efficacy. At a concentration of $0.1 \%$ cerium, reaction (5) outcompetes degradation Path B by a factor of around 800 at ambient temperature, yet this factor drops by more than an order of magnitude at $80{ }^{\circ} \mathrm{C}$. With $1 \%$ Ce the mitigation factor at $80{ }^{\circ} \mathrm{C}$ is only 260 . Figure $3 \mathrm{~b}$ shows the required cerium-ion content for a target mitigation factor of $\mu_{\mathrm{B}}=$ 100. With the rate of radical formation of $r_{\mathrm{HO}}=10^{-6} \mathrm{M} \cdot \mathrm{s}^{-1}$ (Table I) used in the simulation, a membrane lifetime of $280 \mathrm{~h}$ is obtained in the absence of cerium-ions (cf. Supporting Information, section 5). A mitigation factor of 100 , therefore, corresponds to a projected membrane lifetime of $28^{\prime} 000 \mathrm{~h}$.

Indirectly, reaction (5) is also in competition with Path A via the fast equilibrium (3), ${ }^{38,50}$ (Table III) since turnover via Path $\mathrm{A}$ is reduced by the decrease of the total radical concentration through reaction (5) (Eq. 10). At the maximum concentration of $\mathrm{Ce},[\mathrm{Ce}]=$ $0.015 \mathrm{M}, k_{4}+k_{5}[\mathrm{Ce}] \ll k_{-3}\left[\mathrm{H}_{2} \mathrm{O}\right]$, the speciation of $\mathrm{P}-\mathrm{OH}$ vs $\mathrm{P}^{++}$, $K_{3 \text {,eff }}$, is not significantly affected by reactions (4) and (5). Figure 4 shows reaction rates $r_{2}$ (Path A degradation), $r_{4}$ (Path B degradation), the total rate of degradation $r_{2}+r_{4}$, and the rate of cation radical repair $r_{5}$ at a temperature of $80{ }^{\circ} \mathrm{C}$. Neither the temperature dependence of $K_{3}$ nor thatof the rate constants $k_{3}$ and $k_{-3}$ isknown. For the rate constants we use the values at room temperature as low limits and thereby implicitly assume the temperature dependence of

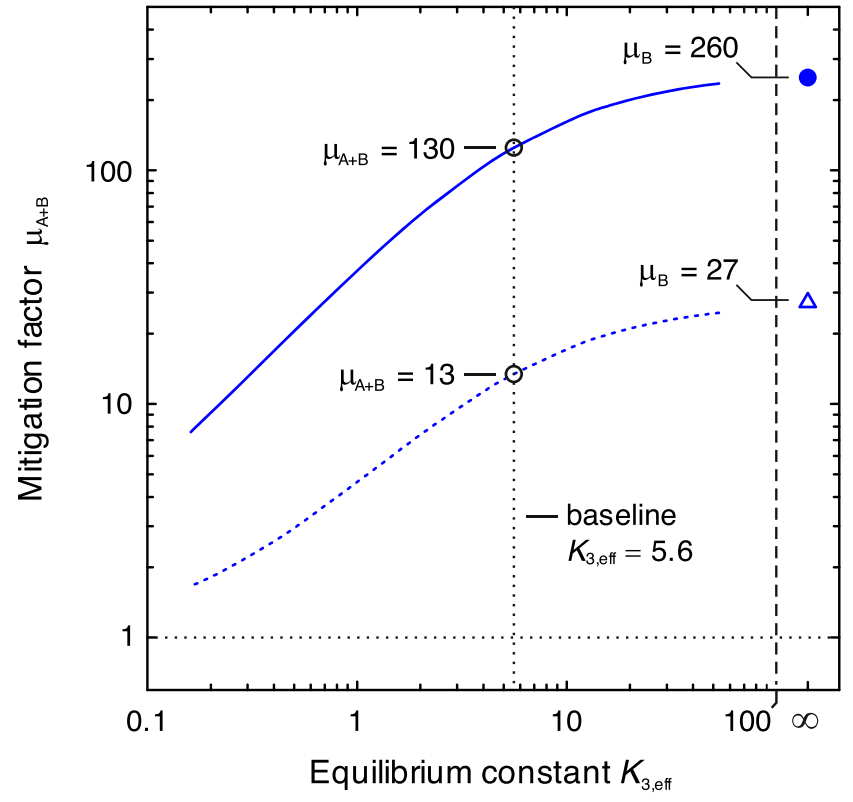

Figure 5. The influence of equilibrium (3) on the total mitigation factor $\mu_{\mathrm{A}+\mathrm{B}}$ at a temperature of $80^{\circ} \mathrm{C}$. The equilibrium constant $K_{3}{ }^{\prime}$, given by $\mathrm{p} K_{3}$ and the $\mathrm{pH}$ of the environment, was changed by varying the rate constant $k_{-3}$ from $2 \cdot 10^{6} \mathrm{M}^{-1} \mathrm{~s}^{-1}$ to $7 \cdot 10^{8} \mathrm{M}^{-1} \mathrm{~s}^{-1}$. The other rate constants were maintained at the values listed in Table III. Due to the fast equilibrium $K_{3, \text { eff }} \approx K_{3}{ }^{\prime}$ (cf. Appendix C). The values at the baseline value of $k_{-3}=$ $2 \cdot 10^{7} \mathrm{M}^{-1} \mathrm{~s}^{-1}$ are indicated. At $K_{3}{ }^{\prime} \rightarrow \infty$, degradation Path A is "switched off."

$K_{3}$ to be negligible. With the model parameters used (Tables I and III), $K_{3}{ }^{\prime}=5.6$, and the ratio $a$ of degradation rates of Paths A and $\mathrm{B}, a=k_{2} /\left(k_{4} \cdot K_{3}{ }^{\prime}\right)=1.1$ (cf. Appendix C). Hence, the rates associated with Path A and Path B are almost identical under the conditions of our model (Fig. 4). In the absence of cerium, the rate of membrane degradation is equal to the rate of $\mathrm{HO}^{\circ}$ attack. Detectable protection of the membrane, via repair reaction (5), begins at a minimum Ce concentration of approximately $0.1 \mathrm{mM}$. At $[\mathrm{Ce}]=$ $1.5 \mathrm{mM}(0.1 \% \mathrm{Ce})$ degradation is reduced by a factor of $\mu_{A+\mathrm{B}}=13$, and by a factor of $\mu_{A+\mathrm{B}}=130$ at $[\mathrm{Ce}]=15 \mathrm{mM}(1 \% \mathrm{Ce})$, Eq. 10 .

\section{Discussion}

The degradation of a fuel cell membrane is a complex process that involves many reactions with very different timescales. In this work, we focus on the initiating reactions, explore the possibility of mitigating damage at an early stage, and attempt a mathematical description of potential efficacy of repair. Most importantly, the "full reaction mechanism" (Scheme 2) is a simplification and, given the current knowledge, partly an assumption. Influences of individual reactions in complex reaction schemes are inherently difficult to disentangle and understand. Therefore, we use classes of reactions to describe the overall process in a simplified kinetic framework. In order to achieve this, we need rate constants, some of which are derived by analogy from similar systems and some of which have been published for different conditions, others we have measured ourselves. In the following sections, we discuss the potential of polymer repair and the limitations of our kinetic framework's ability to describe the actual situation in a fuel cell membrane.

Degradation pathway.-Equilibrium (3) plays a crucial role in our model. For an effective repair reaction, it is of utmost importance to maintain the position of equilibrium (3) on the cation radical side, as cerium only repairs $\mathrm{P}^{+}$, reaction (5). Figure 5 shows the effect of varying the effective equilibrium $\left(K_{3}^{\prime}=K_{3}\right.$ $\left.\cdot\left[\mathrm{H}^{+}\right] /\left[\mathrm{H}_{2} \mathrm{O}\right]\right)$. At low values of $K_{3}{ }^{\prime}$, degradation along pathway A is prevalent and repair of cation radicals by $\mathrm{Ce}$ (III) has little effect 
on membrane stabilization. At high values of $K_{3}^{\prime}$, degradation follows Path $B$ and repair efficacy can be maximized. The influence of $K_{3}^{\prime}$ should be seen as a qualitative study indicating a trend.

Limits of accuracy.-We do not take the data of Fig. 5 as quantitative, because $k_{3}$ and $k_{-3}$ were estimated by analogy, $k_{\text {PathB }}$ carries systematic uncertainty and the (effective) rate constant $k_{\text {PathA }}$ is an estimation, too. Additionally, some of the data collected here rely on assumptions from previous work that have not been confirmed experimentally. Specifically, the rate constant of reaction (5) is determined by following an absorption change in the green part of the visible spectrum during pulse radiolysis. This has been previously interpreted as being caused by the formation of the cation radical, $\mathrm{P}^{+}$, but has not been unambiguously confirmed.

Equilibrium 3. There is little information available in the literature on equilibrium (3), we based the values for $k_{3}$ and $k_{-3}$ used here on data of methylated benzenes in a lab-report from Ris $\varnothing$ National Laboratory (Denmark). ${ }^{38}$ The mechanism of the reaction makes perfect chemical sense and is, in principal, known. However, we are cautious about the reported values of the rate constants and we are not aware of any data for phenylsulfonates. While this problem may influence the numbers obtained from our simulation, it does not compromise the overall picture we want to draw and discuss here.

Path B: As explained in Appendix A, $k_{4}$ is merely estimated and the value we use represents an upper limit of $k_{4}$ relative to $k_{5}$. It is conceivable that the ratio $k_{4} / k_{5}$ is, therefore, lower and consequently the mitigation factor $\mu_{\mathrm{B}}$ is larger.

Path A: As was shown in Fig. 5, Path A has a strong influence on the overall rate of degradation. Unfortunately, $k_{\text {pathA }}$ is not known for elevated temperatures. Previously, Dockheer et al. and Nolte et al. have measured the oxygen-dependent part of Path A at room temperature. ${ }^{25,33}$ However, it is difficult to measure at elevated temperature since the solubility of oxygen in water is strongly temperature dependent and it is not certain that we have full equilibrium conditions in our solution during the experiment. Here, instead, we use an effective rate constant $k_{2}$ characterizing degradation in the presence of oxygen, based on literature values (Appendix D). The room temperature value of $k_{\text {PathA }}=1.4 \cdot 10^{4} \mathrm{~s}^{-1}$ is extrapolated to $80{ }^{\circ} \mathrm{C}$ using an activation energy of $22 \mathrm{~kJ} \mathrm{~mol}^{-1}$ (Table III, see also Fig. S5), which represents an educated guess based on the temperature dependence of the self-decay of $\mathrm{P}-\mathrm{OH}$. This approach is admittedly crude, yet can be justified in view of the lack of experimental data. To probe the influence of the variation of $k_{\text {PathA }}$, we carried out a sensitivity analysis, changing its value at $80^{\circ}$ $\mathrm{C}$ by a factor of 10 . If $k_{\text {PathA }}$ is decreased by a factor of $10\left(k_{\text {PathA }}=\right.$ $\left.5.6 \cdot 10^{3} \mathrm{~s}^{-1}\right) \mu_{\mathrm{A}+\mathrm{B}}$ increases by a factor of 2 , approximately, at a cerium content of $1 \%$. If the rate constant is increased by a factor of $10\left(k_{\mathrm{PathA}}=5.6 \cdot 10^{5} \mathrm{~s}^{-1}\right), \mu_{\mathrm{A}+\mathrm{B}}$ approximately decreases by a factor of 6 . If $k_{2}$ were substantially larger than expected, Path A would be the dominant degradation route and polymer repair by $\mathrm{Ce}(\mathrm{III})$ as proposed here will be ineffective.

Cerium-ions in fuel cell membranes.-The incorporation of cerium-ions into a proton exchange membrane requires us to consider a number of issues. As previously mentioned, ceriumions replace protons in the membrane. This will have an impact on the conductivity of the membrane, which puts a practical limit on the Ce concentration of about $1 \%$ of the sulfonate content. The effectiveness of the repair reaction in the confined environment of an ionomer membrane may be different to the situation of a dilute aqueous solution used in the experiments here. Furthermore, lifetime of intermediates may also be different due to steric restrictions in a membrane. Additionally, cerium-ion diffusivity also needs to be taken into account. The repair action of cerium-ions requires them to be near a "repairable" point of damage, i.e. a cation radical. Since the cation radical is part of the polymer, we consider it to be immobile in a first approximation. Therefore, a cerium-ion needs to be sufficiently close to the location of the cation radical to be able to repair it before irreversible damage occurs. Based on rate constant $k_{4}$ and the associated lifetime of $\mathrm{P}^{+}$, we can estimate whether ceriumions at a certain concentration in the membrane can reach all potential points of damage on the polymer. Therefore, the diffusivity of $\mathrm{Ce}$ (III) as a function of relative humidity has to be considered. It is shown that at a concentration of $0.01 \% \mathrm{Ce}(0.15 \mathrm{mM})$, the average spacing of cerium-ions of $22 \mathrm{~nm}$ allows cerium-ions to reach $\mathrm{P}^{+}$ sites with a probability of more than $99 \%$ at $50 \%$ r.h. (Appendix E). The assumption here is that cerium-ions are evenly distributed. However, cerium-ions are mobile and will migrate towards the cathode under the influence of the electric field, ${ }^{51}$ so (partial) immobilization may be required. Alternatively, the use of ceria based nano-particles ${ }^{52}$ instead of cerium-ions may avoid cerium-ion migration. However, it is questionable if the particles can be sufficiently well dispersed to ensure that points of damage and cerium-ions are close enough for repair. A further issue caused by the degradation of the polymer membrane is that negatively charged ionic species are released (e.g. aromatic sulfonates, sulfates), which can form ion pairs with $\mathrm{Ce}(\mathrm{III})$. This inherently will promote the washing out of $\mathrm{Ce}$ ions during fuel cell operation, which will contribute to a decrease in concentration of cerium over time, making the repair reaction less and less effective. One possible approach to mitigate this effect is to use covalently bound $\mathrm{Ce}(\mathrm{III})$ complexes, based on relatively simple host molecules, such as crown ethers. ${ }^{53,54}$

Finally, we have used an oligomer of PAMSS with a low molecular weight of $14.6 \mathrm{kDa}$ in this study. With the corresponding degree of polymerization of around 60 the polyelectrolyte assumes a coiled configuration that also allows for intra-chain interactions, which may be important to stabilize intermediates. ${ }^{36}$ In a recent article, we studied the dependence of selected reactions on the degree of polymerization of PAMSS and found that, in general, rate constants for reactions of intermediates somewhat decrease for increasing chain lengths due to intramolecular stabilization. ${ }^{39}$

Promising future strategies.-In an operating fuel cell, degradation Path A must be inhibited and the ratio $k_{4} / k_{5}$ must be minimized. The first requirement may be achieved by engineering a polymer where the cyclohexadienyl radical has a lower propensity to react with oxygen and by changing the $\mathrm{pK}_{\mathrm{a}}$ of the polymer so that equilibrium (3) lies on the cation radical side. In principle, the properties of the membrane aromatic units can be tuned by functional groups. Electron-withdrawing groups would reduce the electron density of the HO-adduct, and decrease the rate constant of Path A, i.e. the reaction with oxygen. ${ }^{55}$ Such a strategy also has disadvantages: electron-withdrawing groups on the aromatic units of the polymer will decrease $K_{3}$ and shift the equilibrium towards the HO-adduct as the overall $\mathrm{p} K_{\mathrm{a}}$ of the cation radical is decreased. Conversely, electron-donating groups increase the $\mathrm{pK}_{\mathrm{a}}$ of the cation radical and shift the equilibrium towards the cation radical, thus promoting the efficacy of the repair. However, the rate constant $k_{\text {PathA }}$ will increase. The net overall effect will depend on the chemistry of the building blocks used.

There is, at present, no experimental evidence for damage repair by cerium or other compounds in a working fuel cell. There have been, however, reports of improved stability against attack by $\mathrm{HO}^{\circ}$ of aromatic hydrocarbon membranes containing cerium in an ex situ Fenton test. ${ }^{53,54}$ The observed improvements in stability have been explained by radical quenching. However, considering the fast reaction of $\mathrm{OH}^{-}$with aromatic compounds, it may well be that the stabilizing effect of cerium is in fact a result of the repair of formed intermediates as presented in this work. Dedicated experimental strategies therefore need to be devised to investigate the role of cerium and potentially other additives in a membrane under fuel cell operating conditions. It is important to be able to distinguish mechanistically and quantify kinetically whether an additive is acting as a scavenger or a repair agent. This can potentially be studied using ionomers of defined chemistry with variations in the substituent pattern. It is, however, important to keep in mind that 
modification of the polymer chemistry may accelerate other degradation mechanisms, such as desulfonation and crosslinking. We plan to study the influence of cerium-ion doping on the stability of hydrocarbon-based membranes and investigate the influence of the polymer chemistry on reaction patterns with radicals, cerium-ions and potentially other additives.

\section{Conclusions}

Cerium(III) may repair aromatic hydrocarbon-based ionomers during fuel cell operation. This is achieved by reducing cation radicals, which are formed along with other intermediates, such as the HO-adduct, as a result of $\mathrm{HO}^{\circ}$ attack on the polymer. The efficacy of repair depends on the lifetime of the cation radical and competing degradation mechanisms that are not amenable to repair. The concentration of the different intermediates can likely be influenced by the substituent pattern of the aromatic units. If degradation via intermediates other than cation radicals is dominant, repair is inefficient. Fine-tuning of the repair agent and polymer chemistry offers the prospect of significantly increased membrane lifetime in the fuel cell.

\section{Acknowledgments}

The authors wish to thank the Swiss National Science Foundation (SNSF) for project funding (grant no. 175493). Technical support by Reinhard Kissner, ETH Zürich, is gratefully acknowledged.

\section{Appendix A: Pulse Radiolysis}

A.1. Experimental conditions.-As a biradical, oxygen reacts very quickly with a multitude of radicals. To minimize complications, our solutions were, therefore, deaerated.

Radiolysis ionizes matter about mass-proportionally. Therefore, the effect is measured in energy deposited on the sample per mass unit, i.e. the dose: $1 \mathrm{~Gy}=1 \mathrm{~J} \mathrm{~kg}^{-1}$. With dilute solutions, the energy is quantitatively deposited on the solvent that is ionized. Pulse irradiation of water generates primary species (reaction A.1), with well-known yields. ${ }^{45}$ These radiochemical yields are referred to as the G-value and are traditionally given in in number of species created per $100 \mathrm{eV}$ of deposited energy or, modern, in $10^{-7} \mathrm{M} / \mathrm{Gy}$ radiolysis product. The numbers differ $\sim 4 \%$, due to the interconversion factor between the old and new units $(G($ old $)=0.96485 G$ (new)).

$$
\begin{gathered}
\mathrm{H}_{2} \mathrm{O} \rightsquigarrow \mathrm{HO}, \mathrm{H}^{\prime}, \mathrm{e}_{\mathrm{aq}}{ }^{-}, \mathrm{H}^{+} \\
\mathrm{S}_{2} \mathrm{O}_{8}{ }^{2-}+\mathrm{e}_{\mathrm{aq}}{ }^{-} \rightarrow \mathrm{SO}_{4}{ }^{-}+\mathrm{SO}_{4}{ }^{2-} \\
\mathrm{e}_{\mathrm{aq}}{ }^{-}+\mathrm{H}^{+} \rightarrow \mathrm{H}^{-} \\
\mathrm{N}_{2} \mathrm{O}+\mathrm{H}_{2} \mathrm{O}+\mathrm{e}_{(\mathrm{aq})}{ }^{-} \rightarrow \mathrm{N}_{2}+\mathrm{HO}^{-}+\mathrm{HO}^{-} \\
\mathrm{S}_{2} \mathrm{O}_{8}{ }^{2-}+\mathrm{H} \rightarrow \mathrm{SO}_{4}{ }^{-}+\mathrm{SO}_{4}{ }^{2-}+\mathrm{H}^{+}
\end{gathered}
$$

Radiolysis concomitantly produces reducing and oxidizing species, reaction (A.1). This complicates the mechanistic and kinetic interpretation of successive reactions. Therefore, experimentalists usually add an excess of chemicals that would, eventually, convert primary species to better controlled starting conditions: oftentimes, buffers are used to maintain the proton concentration, hydrated electrons can be converted into oxidizing species, reactions (A.2) and (A.4), and hydroxyl radicals can be converted to strongly reductive species (no examples given). Not always, however, "clean" starting conditions are achievable: the hydrated electron, for example, is a moderately strong base, $\mathrm{p} K_{\mathrm{a}}\left(\mathrm{H}^{\circ}\right)=9.1$, and its reaction with protons is diffusion controlled.

If fuel cell conditions are to be mimicked, experiments should be carried out under strongly acidic conditions. At acidic $\mathrm{pH}$ reaction

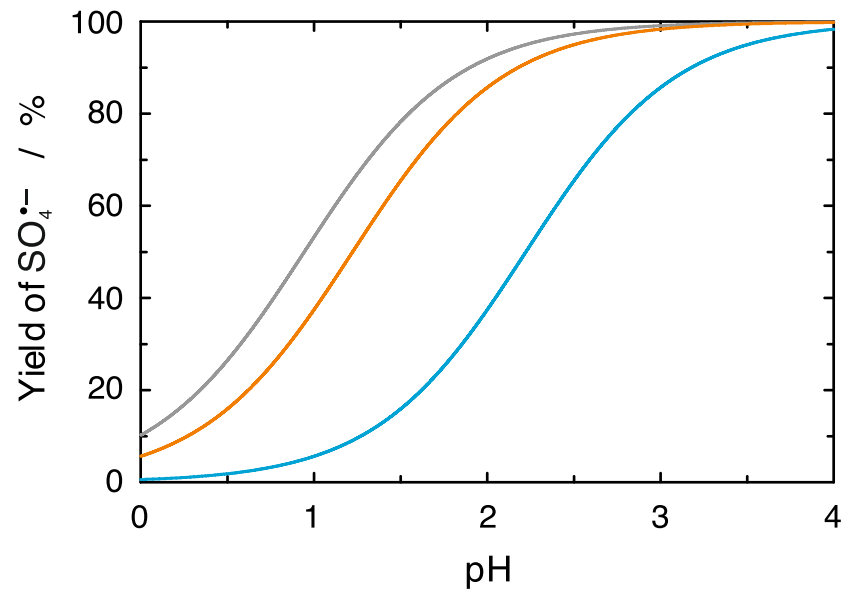

Figure A $\mathbf{1}$. Calculated yield of $\mathrm{SO}_{4}{ }^{-}$from the competition reaction of the hydrated electron with peroxodisulfate vs protons. ${ }^{26}$ Grey curve: with saturation concentration of $190 \mathrm{mM} \mathrm{K} \mathrm{K}_{2} \mathrm{~S}_{2} \mathrm{O}_{8}$, yellow curve: $100 \mathrm{mM}$ $\mathrm{K}_{2} \mathrm{~S}_{2} \mathrm{O}_{8}$ (maximum concentration in presence of PAMSS), blue curve: $10 \mathrm{mM} \mathrm{K} \mathrm{S}_{2} \mathrm{O}_{8}$ (optimum concentration if side reactions with peroxodisulfate are to be avoided).

(A.3) may compete effectively with reaction (A.2), the yield of $\mathrm{SO}_{4}{ }^{-}$decreases with $\mathrm{pH}$ (Fig. A.1). ${ }^{26}$ Additionally, in $\mathrm{N}_{2} \mathrm{O}$-saturated aqueous solutions $\left(24.8 \mathrm{mM}\right.$ at $\left.20{ }^{\circ} \mathrm{C}\right)$, the solvated electron $\mathrm{e}_{(\mathrm{aq})}{ }^{-}$can be converted to $\mathrm{HO}$, reaction (A.4), which, depending on $\mathrm{pH}$ and peroxodisulfate concentration, may also compete with reactions (A.2) and (A.3). Therefore, we used argon saturated solutions.

The formed primary species $\mathrm{H}^{\circ}$ will form an adduct with polymer $\mathrm{P}$, according to reaction (A.6).

$$
\mathrm{P}+\mathrm{H} \rightarrow \mathrm{P}-\mathrm{H}
$$

As reaction (A.6) is diffusion controlled, ${ }^{56}$ it may successfully compete with the much slower reaction (A.5) even if $\left[\mathrm{S}_{2} \mathrm{O}_{8}{ }^{2-}\right] \gg$ $[\mathrm{P}]$. The side product $\mathrm{P}-\mathrm{H}$ compromises the determination of the rate constants of the reactions of interest which follow the oxidative damage of the polymer. This puts practical limits to the applicable pH-range, cf. Fig. A.1 and Table SI. ${ }^{26,57,58}$ We aimed to limit the yield of side reactions to $10 \%$.

Apart from reacting with the aromatic ring of PAMSS, reaction (1) hydroxyl radicals could, in principle, oxidize the aliphatic or the aromatic subunits, reactions $(\mathrm{A} \cdot 7)$ and $(\mathrm{A} \cdot 8)$, but direct oxidation of aromatic subunits is rarely observed (A.8). Hydroxyl radicals, HO, can abstract $\mathrm{H}$ from aliphatic molecules (A.7) but $k_{\mathrm{A}-7}$ is approximately one order of magnitude slower than $k_{1}{ }^{33}$

$$
\begin{gathered}
\mathrm{PCH}_{2} \mathrm{R}+\mathrm{HO} \rightarrow \mathrm{PCHR}+\mathrm{H}_{2} \mathrm{O} \\
\mathrm{P}+\mathrm{HO}^{\cdot} \rightarrow \mathrm{P}^{\cdot+}+\mathrm{OH}^{-}
\end{gathered}
$$

Besides $\mathrm{HO}^{\circ} \mathrm{H}^{-}$and $\mathrm{SO}_{4}{ }^{-}$are also produced. Under our conditions $\mathrm{H}$ exclusively adds to the aromatic ring ( $\mathrm{H}$-adduct, reaction (A.6)), ${ }^{33}$ while $\mathrm{SO}_{4}{ }^{--}$induces electron transfer from the ring, reaction (7); reactions (A.5) and (A.9) are not relevant here.

$$
\mathrm{S}_{2} \mathrm{O}_{8}{ }^{2-}+\mathrm{HO}^{\cdot} \rightarrow \mathrm{S}_{2} \mathrm{O}_{8}^{--}+\mathrm{HO}^{-}
$$

Because our polymer contains sulfonate groups we chose to use sulfate as anion both for the added acid and the Ce(III). Considering all competing reactions, we conclude the practical maximum concentration of $\mathrm{H}_{2} \mathrm{SO}_{4}$ for standard experiments to be $1 \mathrm{mM}$. This is much less acidic than fuel-cell conditions, $\mathrm{pH} \approx 0$.

A.2. Data analysis.-Scheme 2 (main text) shows that the products of oxidation of PAMSS by $\mathrm{OH}$ and $\mathrm{SO}_{4}{ }^{-}$are linked by 
reaction (3). This reaction has a low free energy. Consequently, an equilibrium is observed. The speciation of this purportedly fast equilibrium depends on $\mathrm{pH}^{38}$ For the relatively electron-deficient, thus very acidic, aromatic sulfonates the $\mathrm{p} K_{\mathrm{a}, 3}$ is expected to be much lower than the one reported for the more electron rich anisole $\left(\mathrm{p} K_{\mathrm{a}} \approx 3\right){ }^{49}$

$$
\text { P-OH }+\mathrm{H}^{+} \rightarrow \mathrm{P}^{++}+\mathrm{H}_{2} \mathrm{O}
$$

We monitored the decay of the absorption band at $560 \mathrm{~nm}$, perceived to stem from the cation radical $\mathrm{P}^{+}$, to describe reaction (5). The observation of $k_{5}$, however, is only indirect and we rationalize the observations as follows: there is a fast equilibrium $K_{3}$ coupled to decay reactions (5) and Path B. To simplify notation, we refer to the reactions associated with the decay of the $560 \mathrm{~nm}$ band as reaction $(\mathrm{A} \cdot 10)$ with rate constant $\mathrm{k}_{\mathrm{A}-10}$.

$$
\begin{gathered}
\mathrm{P}^{++} \rightarrow \text { Prod } \\
\mathrm{d}[\mathrm{Prod}] / \mathrm{dt}=\mathrm{k}_{A-10}\left[\mathrm{P}^{\cdot+}\right] \\
{[\mathrm{P}-\mathrm{OH}]=\left[\mathrm{P}^{++}\right] / K_{3}{ }^{\prime}} \\
{\left[\mathrm{P}^{*}\right]=\left[\mathrm{P}^{++}\right]+[\mathrm{P}-\mathrm{OH}]=\left[\mathrm{P}^{\cdot+}\right] \cdot\left(1+1 / K_{3}{ }^{\prime}\right)} \\
=\left[\mathrm{P}^{\cdot+}\right] \cdot\left(1+K_{3}{ }^{\prime}\right) / K_{3}{ }^{\prime} \\
{\left[\mathrm{P}^{++}\right]=\left[\mathrm{P}^{*}\right] \cdot K_{3}{ }^{\prime} /\left(1+K_{3}{ }^{\prime}\right)}
\end{gathered}
$$

where $\left[\mathrm{P}^{*}\right]$ is the total concentration of PAMSS radicals in the reaction Scheme 2. Because $\left[\mathrm{P}^{+}\right]$is always proportional to $\left[\mathrm{P}^{*}\right]$ and $[\mathrm{P}-\mathrm{OH}]$, and because $\left[\mathrm{P}^{*}\right]$ decays only via reaction $(\mathrm{A} \cdot 10)$

$$
\begin{gathered}
\mathrm{d}[\operatorname{Prod}] / \mathrm{dt}=k_{\mathrm{A}-10}\left[P^{++}\right]=k_{A-10} \cdot\left[\mathrm{P}^{*}\right] \cdot K_{3}{ }^{\prime} /\left(1+K_{3}{ }^{\prime}\right) \\
k_{\mathrm{A}-10, \text { obs }}=k_{\mathrm{A}-10} \cdot K_{3}{ }^{\prime} /\left(1+K_{3}{ }^{\prime}\right) \leqslant k_{\mathrm{A}-10}
\end{gathered}
$$

Therefore, as the decay of PAMSS-radicals is observed, the observed rate constant is not $\mathrm{k}_{\mathrm{A}-10}$ but $k_{\mathrm{A}-10} \cdot K_{3}{ }^{\prime} /\left(1+K_{3}{ }^{\prime}\right)$. As we do have no literature reports on $K_{3}$, we assume $\left[\mathrm{P}^{*}\right]=\left[\mathrm{P}^{+}\right]$. This affects both the measurement of $\mathrm{k}_{5}$ and $\mathrm{k}_{\mathrm{Path}} \mathrm{B}$ : at sufficiently high [Ce(III)] $k_{\mathrm{A}-10 \text {,obs }}=\mathrm{k}_{5 \text {,obs }}$ and represents the low limit of the associated $k_{5}=\mathrm{k}_{\mathrm{A}-10}$ which, depending on $K_{3}{ }^{\prime}$, might be orders of magnitude higher. This is also true for $[\mathrm{Ce}(\mathrm{III})]=0$, where $k_{\mathrm{Path} \mathrm{B}}=$ $\mathrm{k}_{\mathrm{A}-10}$. But here there is an additional problem. Path $\mathrm{B}$ should be investigated under conditions where no radical recombination occurs and this requires minimal radical concentration. The observed rate constants are several orders of magnitude slower than repair. It is, therefore best observed at minimal dose, which implies a minimal signal-to-noise ratio: under our conditions we cannot unambiguously pinpoint any second-order contributions to our trace anymore, be it because of their real absence or the limited precision of the detection. Because the influence of equilibrium (3) and possible second order contributions have an opposite effect, we do not exactly know in which way Path B is influenced. It is clear, however, that our data sets a lower limit of $k_{5} / k_{\mathrm{PathB}}$ and represents, therefore, a conservative estimation for the $\mathrm{Ce}(\mathrm{III})$-related repair efficacy.

\section{Appendix B: Stopped Flow}

The following redox reactions were considered.

$$
\begin{aligned}
& \mathrm{Ce}(\mathrm{IV})+\mathrm{H}_{2} \mathrm{O}_{2} \rightarrow \mathrm{Ce}(\mathrm{III})+\mathrm{HOO}+\mathrm{H}^{+} \\
& \mathrm{Ce}(\mathrm{IV})+\mathrm{HOO}^{\circ} \rightarrow \mathrm{Ce}(\mathrm{III})+\mathrm{O}_{2}+\mathrm{H}^{+}
\end{aligned}
$$

The rate constants $k_{6}{ }^{\prime}$ obtained from the pseudo-first order kinetic analysis were plotted vs the reactant concentration, Fig. S11. The slope corresponds to the second-order rate constants, Table B.II (see
Table B·I. Concentration of cerium and $\mathrm{H}_{2} \mathrm{O}_{2}$ in the stopped flow experiments. Solutions were prepared in $0.1 \mathrm{M}$ sulfuric acid $(\mathrm{pH} \approx 1)$.

\begin{tabular}{lcccc}
\multicolumn{2}{c}{ Cerium excess } & & \multicolumn{2}{c}{ Peroxide excess } \\
\cline { 1 - 2 } \cline { 5 - 5 } $\mathrm{Ce}(\mathrm{IV})(\mathrm{mM})$ & $\mathrm{H}_{2} \mathrm{O}_{2}(\mathrm{mM})$ & & $\mathrm{H}_{2} \mathrm{O}_{2}(\mathrm{mM})$ & $\mathrm{Ce}(\mathrm{IV})(\mathrm{mM})$ \\
\hline 0.29 & 0.03 & & 0.3 & 0.03 \\
0.2 & 0.02 & & 1 & 0.1 \\
0.1 & .01 & & & \\
0.03 & .005 & & &
\end{tabular}

Table B·II. Extracted rate constant from Fig. S11 from linear least square fits.

\begin{tabular}{cccc}
$\begin{array}{l}\text { Temperature } \\
{ }^{\circ} \mathrm{C}\end{array}$ & $\begin{array}{c}\text { 2nd order rate con- } \\
\text { stant } k_{6}\left(10^{6} \mathrm{M}^{-1} \mathrm{~s}^{-1}\right)\end{array}$ & $\begin{array}{c}\text { Standard error } \\
\left(10^{6} \mathrm{M}^{-1} \mathrm{~s}^{-1}\right)\end{array}$ & $\begin{array}{c}\text { Standard } \\
\text { error }(\%)\end{array}$ \\
\hline 10 & 0.40 & 0.07 & 17 \\
25 & 0.82 & 0.09 & 11 \\
50 & 1.8 & 0.2 & 11 \\
75 & 4.2 & 0.9 & 21
\end{tabular}

also Table SI). At the detection wavelength, $320 \mathrm{~nm}$, the produced $\mathrm{Ce}$ (III) does not absorb light (Figs. S6-S9) and we expect to observe only reaction (6). With Ce(IV) in excess, we observe an absorbance change according to a 2:1 stoichiometry, reactions (6) and (B.1), leading to a conversion of $20 \% \mathrm{Ce}(\mathrm{IV})$. With $\mathrm{H}_{2} \mathrm{O}_{2}$ in excess, all $\mathrm{Ce}$ (IV) is reduced.

The kinetics traces, however, clearly indicate that the reaction under scrutiny is not the only one taking place. While deviations in the first $2 \mathrm{~ms}$ in Fig. S10 may be tentatively dismissed as mixing issues, related to the technical limitations of the instrument, the deviations at later stages point to more complex chemistry. This is not surprising, since the observed electron transfer will be preceded and followed by ligand exchange reactions at the metal center. Ligand exchange can often be traced by absorption spectroscopy, for example cerium- $\mathrm{H}_{3} \mathrm{PO}_{4}$ and cerium- $\mathrm{H}_{2} \mathrm{SO}_{4}$ complexes exhibit their absorbance maxima at different wavelength. ${ }^{59}$ Note that the deviation from first-order is small compared to the full absorption change visible in the inset and the influence appears amplified in the double logarithmic plot. In the experimental results shown, the timescales of reaction (6) and the reaction causing the later absorption change are sufficiently separated to warrant a reliable and meaningful fit.

\section{Appendix C: Analysis of the Kinetic Scheme}

We stipulate in our model that all of the $\mathrm{HO}^{\circ}$ react with the polymer P. Eventually, the formed polymer intermediates undergo degradation according to Path $\mathrm{A}$ and $\mathrm{B}$, or react with $\mathrm{Ce}$ (III) whereby the parent compound $\mathrm{P}$ is restored. Under the assumption of a steady state, the rate of polymer attack has to equal to sum of rates of reactions (2), (4), and (5) (Scheme 2):

$$
r_{\mathrm{HO}}=k_{\mathrm{eff}[\mathrm{P} *]} \cdot\left[\mathrm{P}^{*}\right]=r_{2}+r_{4}+r_{5}=k_{2} \cdot[\mathrm{P}-\mathrm{OH}]+\left(k_{4}+k_{5} \cdot[\mathrm{Ce}(\mathrm{III})]\right) \cdot\left[\mathrm{P}^{+}\right]
$$

We define a total concentration of intermediates [P*] and a "lumped" effective first-order rate constant $k_{\text {eff }}$ to describe the reactions $\mathrm{P}^{*}$ undergoes, reaction (8). The concentration of intermediates $\left[\mathrm{P}^{*}\right]=$ $[\mathrm{P}-\mathrm{OH}]+\left[\mathrm{P}^{+}\right]$is therefore $\left[\mathrm{P}^{*}\right]=r_{\mathrm{HO}} / k_{\text {eff }}$. We now express the concentration of the $\mathrm{HO}$-adduct, $[\mathrm{P}-\mathrm{OH}]$, and cation radical, $\left[\mathrm{P}^{++}\right]$, as a molar fraction $X$ of the total concentration of intermediates $\left[\mathrm{P}^{*}\right]$ and obtain:

$$
r_{\mathrm{HO}}=\left(k_{2} \cdot X(\mathrm{P}-\mathrm{OH})+\left(k_{4}+k_{5} \cdot[\mathrm{Ce}(\mathrm{III})]\right) \cdot X\left(\mathrm{P}^{++}\right)\right) \cdot\left[\mathrm{P}^{*}\right]
$$


We use the effective first-order rate constants $k_{2}$ and $k_{4}$ to describe the degradation along Path A and B, respectively, (Scheme 2) and formulate the steady-state condition for the intermediates:

$$
\begin{aligned}
& \frac{d}{d t}[\mathrm{P}-\mathrm{OH}]=r_{\mathrm{HO} \cdot}-k_{2}[\mathrm{P}-\mathrm{OH}] \\
& -k_{3}\left[\mathrm{H}^{+}\right][\mathrm{P}-\mathrm{OH}]+k_{-3}\left[\mathrm{H}_{2} \mathrm{O}\right]\left[\mathrm{P}^{\cdot+}\right]=0 \\
& \frac{\mathrm{d}}{\mathrm{dt}}\left[\mathrm{P}^{\cdot+}\right]=k_{3}\left[\mathrm{H}^{+}\right][\mathrm{P}-\mathrm{OH}]-k_{-3}\left[\mathrm{H}_{2} \mathrm{O}\right]\left[\mathrm{P}^{\cdot+}\right] \\
& -k_{4}\left[\mathrm{P}^{\cdot+}\right]-k_{5}[\mathrm{Ce}]\left[\mathrm{P}^{\cdot+}\right]=0
\end{aligned}
$$

From the latter equation, we can now find an expression for the concentration ratio of the intermediates:

$$
\begin{aligned}
& \frac{\left[\mathrm{P}^{++}\right]}{[\mathrm{P}-\mathrm{OH}]}=\frac{X\left(\mathrm{P}^{++}\right)}{X(\mathrm{P}-\mathrm{OH})}=\frac{k_{3}\left[\mathrm{H}^{+}\right]}{k_{-3}\left[\mathrm{H}_{2} \mathrm{O}\right]+k_{4}+k_{5}[\mathrm{Ce}]} \\
& =: K_{3, \text { eff }}
\end{aligned}
$$

We define the ratio $\left[\mathrm{P}^{+}\right] /[\mathrm{P}-\mathrm{OH}]$ as $K_{3, \text { eff }}$ as opposed to $K_{3}{ }^{\prime}=$ $k_{3}\left[\mathrm{H}^{+}\right] / k_{-3}\left[\mathrm{H}_{2} \mathrm{O}\right]$, the equilibrium position. However, as is shown in the main text, equilibration (3) is fast and $k_{4}+k_{5}[\mathrm{Ce}] \ll k_{-3}\left[\mathrm{H}_{2} \mathrm{O}\right]$, hence $K_{3 \text {,eff }} \approx K_{3}{ }^{\prime}$, and we can use $K_{3}{ }^{\prime}$ instead of $K_{3 \text {,eff }}$ with an error $<1 \%$.

We assume that the cation radical $\mathrm{P}^{+}$can be repaired by $\mathrm{Ce}(\mathrm{III})$, reaction (5), which is in competition with degradation Path $B$, reaction (4). We are interested which degradation route, Path A or B, is dominant. Therefore, we define the ratio $a$ of the reaction rates representing irreversible degradation:

$$
a=\frac{r_{2}}{r_{4}}=\frac{k_{2}[\mathrm{P}-\mathrm{OH}]}{k_{4}\left[\mathrm{P}^{+}\right]}=\frac{k_{2}}{k_{4}} \frac{1}{K_{3}^{\prime}}
$$

Therefore, the fraction of Path A degradation is $f_{\mathrm{A}}=a /(1+a)$, and the fraction of Path $\mathrm{B}$ degradation $f_{\mathrm{B}}=1 /(1+a)^{\mathrm{a}}$. At the considered concentration of cerium-ions up to $\sim 0.01 \mathrm{M}$ in the polymer $(\sim 1 \%$ with respect to the content of sulfonate groups), the rapid equilibrium between $\mathrm{P}-\mathrm{OH}$ and $\mathrm{P}^{+}$will not be significantly affected (as mentioned above), and the values of $f_{\mathrm{A}}$ and $f_{\mathrm{B}}$ can be considered constant.

In a first approach, our interest is to assess the efficacy of the repair reaction 5 to reduce the likelihood of degradation along Path $\mathrm{B}$. The reaction between $\mathrm{P}^{++}$and $\mathrm{Ce}(\mathrm{III})$ is in competition with Path $B$ degradation, reaction (4). In the absence of cerium, the cation radical $\mathrm{P}^{+}$formed at a rate of $r_{\mathrm{P} .+}$ reacts exclusively along Path $\mathrm{B}$ with the same rate $r_{4,0}$ :

$$
r_{4,0}=k_{4}\left[\mathrm{P}^{\cdot+}\right]_{0}=r_{\mathrm{P}^{+}}
$$

where $\left[\mathrm{P}^{*+}\right]_{0}$ is the cation radical concentration in the absence of cerium. In the presence of cerium, the cation radical undergoes degradation, reaction (4), as well as repair, reaction (5):

$$
r_{4}+r_{5}=\left(k_{4}+k_{5}[\mathrm{Ce}]\right) \cdot\left[\mathrm{P}^{\cdot+}\right]=r_{\mathrm{P}^{+}}
$$

The rate of $\mathrm{P}^{++}$formation $r_{\mathrm{P} .+}$ is largely independent on the presence of cerium owing to the rapid equilibrium $3 /-3$ (as mentioned above). In the presence of cerium-ions, the rate of degradation along Path B is lowered. We form the ratio of reaction rates with cerium, $r_{4}$, and without cerium, $r_{4,0}$ :

$$
\frac{r_{4}}{r_{4,0}}=\frac{k_{4}\left[\mathrm{P}^{+}\right]}{k_{4}\left[\mathrm{P}^{\cdot+}\right]_{0}}=\frac{k_{4}}{k_{4}+k_{5}[\mathrm{Ce}]}=\frac{1}{\mu_{\mathrm{B}}}
$$

Thus, we have defined the mitigation factor $\mu_{\mathrm{B}}$ for degradation along Path B:

$$
{ }^{\mathrm{b}} \text { since } f_{\mathrm{A}}=\frac{r_{2}}{r_{2}+r_{4}}=\frac{r_{2} / r_{4}}{r_{2} / r_{4}+1}=\frac{a}{a+1} \text { and } f_{\mathrm{B}}=1-f_{\mathrm{A}}=1-\frac{a}{a+1}=\frac{1}{a+1} \text {. }
$$

$$
\mu_{\mathrm{B}}=1+\frac{k_{5}[\mathrm{Ce}]}{k_{4}}
$$

The total degradation rate of the polymer along both Paths A and B is

$$
r_{\mathrm{deg}}=r_{\mathrm{A}}+r_{\mathrm{B}}=\left(k_{2} \cdot X(\mathrm{P}-\mathrm{OH})+k_{4} \cdot X\left(\mathrm{P}^{++}\right)\right) \cdot\left[\mathrm{P}^{*}\right]
$$

where the total concentration of intermediates $\left[\mathrm{P}^{*}\right]$ is dependent on the cerium concentration (cf. Eqs. C.1 and C.2). The degradation rate in the absence of cerium is simply

$$
r_{\mathrm{deg}, 0}=r_{\mathrm{HO}}=\left(k_{2} \cdot X(\mathrm{P}-\mathrm{OH})+k_{4} \cdot X \mathrm{P}^{++}\right) \cdot\left[\mathrm{P}^{*}\right]_{0}
$$

We can now write the degradation rate $r_{\text {deg }}$, using equation C.10 and considering equation $\mathrm{C} \cdot 2$, normalized to the one without cerium doping $r_{\mathrm{deg}, 0}=r_{\mathrm{HO}}$. as

$$
\begin{aligned}
& \frac{r_{\mathrm{deg}}}{r_{\mathrm{deg}, 0}}=\frac{\left[\mathrm{P}^{*}\right]}{\left[\mathrm{P}^{*}\right]_{0}}=\frac{k_{2} \cdot X(\mathrm{P}-\mathrm{OH})+k_{4} \cdot X\left(\mathrm{P}^{++}\right)}{k_{2} \cdot X(\mathrm{P}-\mathrm{OH})+\left(k_{4}+k_{5}[\mathrm{Ce}]\right) \cdot X\left(\mathrm{P}^{++}\right)} \\
& =\frac{1}{\mu_{\mathrm{A}+\mathrm{B}}}
\end{aligned}
$$

The expression serves as a definition of the total mitigation factor $\mu_{\mathrm{A}+\mathrm{B}}$, which considers both degradation along Paths $\mathrm{A}$ and $\mathrm{B}$. We can now express $\mu_{\mathrm{A}+\mathrm{B}}$, considering equation $\mathrm{C}-5$ and $K_{3}{ }^{\prime} \approx K_{3 \text {,eff }}$ (cf. above):

$$
\mu_{\mathrm{A}+\mathrm{B}}=1+\frac{k_{5}[\mathrm{Ce}]}{k_{2} / K_{3}{ }^{\prime}+k_{4}}=1+f_{\mathrm{B}} \frac{k_{5}[\mathrm{Ce}]}{k_{4}}
$$

\section{Appendix D: Obtaining Rate Constant $\boldsymbol{k}_{\mathbf{2}}$}

In previous work, ${ }^{25,33}$ we have identified the following pathway for poly(styrene sulfonate) (PSS) degradation from the $\mathrm{OH}$-adduct: with the room temperature rate constants $k_{\mathrm{D} 1}=4.8 \cdot 10^{6} \mathrm{M}^{-1} \mathrm{~s}^{-1}, 39$ $k_{-\mathrm{D} 1}=4.5 \cdot 10^{3} \mathrm{~s}^{-1},{ }^{33}$ and $k_{\mathrm{D} 2}=2.7 \cdot 10^{3} \mathrm{~s}^{-1} \cdot{ }^{60,61}$ For the simulation in this study, we condense this reaction sequence in Scheme D.1 to degradation Path A, reaction 2 (cf. main text) with the rate expressed as $r_{2}=k_{2}[\mathrm{P}-\mathrm{OH}]$. To obtain the rate constant $k_{2}=k_{\mathrm{D} 2 \text {,eff }}$, we stipulate steady state concentration of the intermediate $\mathrm{OO}-\mathrm{P}-\mathrm{OH}$ :

$$
\begin{gathered}
\frac{\mathrm{d}[\cdot \mathrm{OO}-\mathrm{P}-\mathrm{OH}]}{d t}=k_{\mathrm{D} 1}\left[\mathrm{O}_{2}\right][\mathrm{P}-\mathrm{OH}] \\
-\left(k_{-\mathrm{D} 1}+k_{\mathrm{D} 2}\right)[\mathrm{OO}-\mathrm{P}-\mathrm{OH}]=0
\end{gathered}
$$

from which we obtain

$$
[\mathrm{OO}-\mathrm{P}-\mathrm{OH}]=\frac{k_{\mathrm{D} 1}\left[\mathrm{O}_{2}\right]}{k_{-\mathrm{D} 1}+k_{\mathrm{D} 2}}[\mathrm{P}-\mathrm{OH}]
$$

and thus

$$
r_{2}=r_{\mathrm{D} 2}=k_{\mathrm{D} 2}[\mathrm{OO}-\mathrm{P}-\mathrm{OH}]=k_{\mathrm{D} 2} \frac{k_{\mathrm{D} 1}\left[\mathrm{O}_{2}\right]}{k_{-\mathrm{D} 1}+k_{\mathrm{D} 2}}[\mathrm{P}-\mathrm{OH}]
$$

to obtain the rate constant $k_{2}$ for Path A degradation at $25{ }^{\circ} \mathrm{C}$ of

$$
k_{2}=k_{\mathrm{D} 2} \frac{k_{\mathrm{D} 1}\left[\mathrm{O}_{2}\right]}{k_{-\mathrm{D} 1}+k_{\mathrm{D} 2}}=1.4 \cdot 10^{4} \mathrm{~s}^{-1}
$$

where we have assumed an oxygen concentration of $7.5 \mathrm{mM} .^{25}$

The temperature dependence of the equilibrium constant $K_{\mathrm{D} 1}=$ $k_{\mathrm{D} 1} / k_{-\mathrm{D} 1}$ can be estimated as follows. At $25{ }^{\circ} \mathrm{C} K_{\mathrm{D} 1}=1.1 \cdot 10^{3} \mathrm{M}^{-1}$, and with $\Delta G=-R T \cdot \ln K$ we obtain $\Delta G=-17 \mathrm{kJmol}^{-1}$. With an 

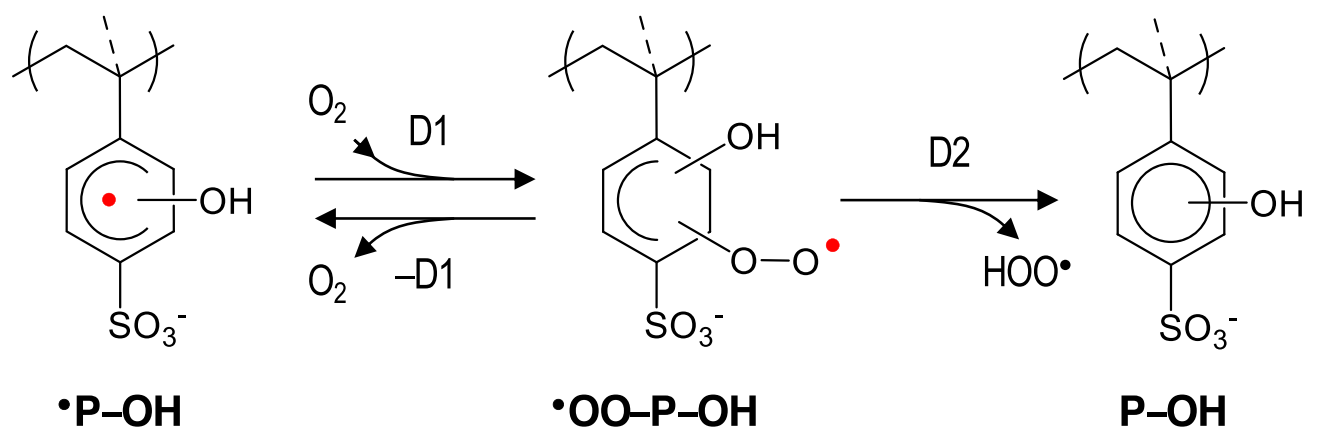

Scheme D·1. Reaction sequence showing the reversible addition of oxygen to the OH-adduct, P-OH (reactions D1 and -D1). The formed OO-P-OH can eliminate $\mathrm{HOO}^{\circ}$ (reaction $\mathrm{D} 2$ ) to yield a hydroxylated product, $\mathrm{P}-\mathrm{OH}$.

estimated reaction entropy of $\Delta S=-159 \mathrm{Jmol}^{-1} \mathrm{~K}^{-1}$ (Ref. 62) a reaction enthalpy of $\Delta H=-65 \mathrm{kJmol}^{-1}$ is calculated. With this and the Van't Hoff equation, we obtain $K_{\mathrm{D} 1}=18 \mathrm{M}^{-1}$ at $80{ }^{\circ} \mathrm{C}$. Therefore, with increasing temperature the equilibrium shifts to $\mathrm{P}-\mathrm{OH}$. However, we do not know the temperature dependence of $k_{\mathrm{D} 2}$. In the simulation, the value of $1.4 \cdot 10^{4} \mathrm{~s}^{-1}$ (Eq. D.6) is used at room temperature, and, in lack of a better alternative, extrapolated to $80{ }^{\circ} \mathrm{C}$ using the activation energy of $22 \mathrm{~kJ} \mathrm{~mol}^{-1}$ determined from the self-decay of the HO-adduct in the absence of oxygen (rate $k_{2}$, Fig. 2), yielding a value of $5.6 \cdot 10^{4} \mathrm{~s}^{-1}$. In view of the uncertainty associated with the kinetics of Path A degradation, we performed a study on the effect of the variation of the equilibrium between $\mathrm{P}-\mathrm{OH}$ and $\mathrm{P}^{+}$and the fraction of Path A degradation (cf. Fig. 5 and related text).

\section{Appendix E: Spacing and Diffusivity of Cerium-Ions}

The cation radicals $\mathrm{P}^{+}$are part of the polymer structure and therefore largely immobilized. For Ce(III) to act as a repair agent, the nearest ions need to be able to diffuse to the location of $\mathrm{P}^{+}$to repair it before it undergoes a detrimental degradation reaction. The available time for a repair to take place is given by the lifetime of the cation radical, which can be calculated from its effective rate constant for first-order decay, $k_{4}$. At $80{ }^{\circ} \mathrm{C}, k_{4}=9 \cdot 10^{3} \mathrm{~s}^{-1}$ (Table III). The time $\tau_{\alpha}$ for a fraction $\alpha$ of $\mathrm{P}^{+}$to decay is given by $\tau_{\alpha}=-\ln (1-\alpha) / k_{4}$. At the same time, within this time span, ceriumions diffuse on average over a distance $L$ given by $L=\sqrt{4 D \tau_{a}}$ (diffusion length). The diffusion coefficient of Ce(III) in a PFSA membrane has been determined by Coms et al. ${ }^{63}$, at $80{ }^{\circ} \mathrm{C} D=$ $5 \cdot 10^{-5} \mathrm{~cm}^{2} \mathrm{~s}^{-1}$ at a relative humidity (r.h.) of $100 \%$, and $D=4 \cdot 10^{-7}$ $\mathrm{cm}^{2} \mathrm{~s}^{-1}$ at $50 \%$ r.h. The diffusion length $L$ of $\mathrm{Ce}$ (III) for different lifetime values $\tau_{\alpha}$ of $\mathrm{P}^{+}$is listed in Table E.I.

The average separation $d$ of cerium-ions in the membrane, assuming homogeneous distribution and a simple cubic lattice, is given by $d=\left([\mathrm{Ce}] \cdot N_{\mathrm{A}}\right)^{-1 / 3}$, where $N_{\mathrm{A}}$ is the Avogadro constant. Table E.II lists a few values for practical cerium-ion concentrations. Therefore, we see that at practical target concentrations of cerium in

Table E.I. Time $\tau_{\alpha}$ to the loss of a fraction $\alpha$ of cation radicals $\mathrm{P}^{++}$at $80{ }^{\circ} \mathrm{C}$ due to Path B degradation, and associated diffusion length $L$ of $\mathrm{Ce}(\mathrm{III})$ at two different relative humidities.

\begin{tabular}{|c|c|c|c|}
\hline \multicolumn{2}{|c|}{ Cation radicals $\mathrm{P}^{+}$} & \multicolumn{2}{|c|}{ Cerium-ions } \\
\hline $\begin{array}{l}\text { Fraction decayed } \\
\alpha\end{array}$ & $\begin{array}{c}\text { Time } \\
\tau_{\alpha}(\mu \mathrm{s})\end{array}$ & $\begin{array}{c}L(100 \% \text { r.h. }) \\
(\mathrm{nm})\end{array}$ & $\begin{array}{c}L(50 \% \text { r.h. }) \\
(\mathrm{nm})\end{array}$ \\
\hline $5 \%$ & 6 & 340 & 30 \\
\hline $10 \%$ & 12 & 480 & 43 \\
\hline $50 \%$ & $77^{\text {a) }}$ & $1 ’ 200$ & 110 \\
\hline
\end{tabular}

a) half-life.

$\begin{aligned} & \text { Table E-II. Average spacing } \boldsymbol{d} \text { of cerium-ions in the membrane as a } \\
& \text { function of concentration (doping level). }\end{aligned}$
\begin{tabular}{lcc} 
\\
{$[\mathrm{Ce}] /\left[\mathrm{P}-\mathrm{SO}_{3}{ }^{-}\right](\%)$} & {$[\mathrm{Ce}](\mathrm{mM})$} & $d(\mathrm{~nm})$ \\
\hline $0.01 \%$ & 0.15 & 22 \\
$0.1 \%$ & 1.5 & 10 \\
$1 \%$ & 15 & 4.8
\end{tabular}

the membrane, the spacing of ions is sufficiently small for them to reach a significant fraction of cation radicals $\mathrm{P}^{+}$within their expected lifetime to repair the damage.

\section{ORCID}

Tym de Wild (iD https://orcid.org/0000-0002-6412-6548

Tamas Nemeth (iD https://orcid.org/0000-0003-4739-5882

Tom M. Nolte (iD https://orcid.org/0000-0001-8083-0749

Thomas J. Schmidt (iD https://orcid.org/0000-0002-1636-367X

Thomas Nauser (iD https://orcid.org/0000-0002-5692-5737

Lorenz Gubler (iD https://orcid.org/0000-0002-8338-6994

\section{References}

1. T. Suzuki, A. Iiyama, N. Kubo, N. Saito, K. Shinohara, S. Shimotori, Y. Sugawara, and K. Yamada, ECS Trans., 92, 3 (2019).

2. W. Liu, K. Ruth, and G. Rusch, J. New Mater. Electrochem. Syst., 4, 227 (2001).

3. D. E. Curtin, R. D. Lousenberg, T. J. Henry, P. C. Tangeman, and M. E. Tisack, J. Power Sources, 131, 41 (2004).

4. M. Gebert, A. Ghielmi, L. Merlo, M. Corasaniti, and V. Arcella, ECS Trans., 26, 279 (2010).

5. M. A. Yandrasits and S. J. Hamrock, "Membranes for PEM Fuel Cells." Fuel Cell Chemistry and Operation, ed. A. M. Herring, T. A. ZawodzinskiJr., and S J. Hamrock (American Chemical Society, Washington, DC) ACS Symposium Series, 1040, 15 (2010).

6. B. Kienitz, J. Kolde, S. Priester, C. Baczkowiski, and M. Crum, ECS Trans., 41, 1521 (2011).

7. E. Endoh, "Electrolyte membrane for polymer electrolyte fuel cell, process for it production and membrane-electrode assembly for polymer electrolyte fuel cell." US Pat. 2007/0111076, Asahi Glass Co., USA (2007).

8. F. D. Coms, S. Schlick, and M. Danilczuk, "Stabilization of Perfluorinated Membranes Using $\mathrm{Ce}^{3+}$ and $\mathrm{Mn}^{2+}$ Redox Scavengers: Mechanisms and Applications." The Chemistry of Membranes Used in Fuel Cells: Degradation and Stabilization, ed. S. Schlick (Wiley, Hoboken) 75 (2018)

9. S. Kinoshita, T. Shimohira, A. Watakabe, S. Hommura, S. Saito, T. Tanuma, and K. Yamada, ECS Trans., 75, 575 (2016).

10. V. R. Stamenkovic and N. M. Markovic, "Oxygen Reduction on Platinum Bimetallic Alloy Catalysts." Handbook of Fuel Cells, ed. W. Vielstich, H. A. Gasteiger, and H. Yokokawa (Wiley, Chichester, United Kingdom) 5, 18 (2009).

11. A. Rabis, P. Rodriguez, and T. J. Schmidt, ACS Catal., 2, 864 (2012).

12. K. C. Neyerlin, W. Gu, J. Jorne, and H. A. Gasteiger, J. Electrochem. Soc., 153, A1955 (2006).

13. V. Yarlagadda, M. K. Carpenter, T. E. Moylan, R. S. Kukreja, R. Koestner, W. Gu, L. Thompson, and A. Kongkanand, ACS Energy Lett., 3, 618 (2018).

14. S. M. MacKinnon, T. J. Fuller, F. D. Coms, M. R. Schoeneweiss, C. S. Gittleman, Y. H. Lai, R. Jiang, and A. M. Brenner, "Membranes: Design and Characterization." Encyclopedia of Electrochemical Power Sources, ed. J. Garche (Elsevier, Amsterdam) 741 (2015). 
15. G. Maier and J. Meier-Haack, Adv. Polym. Sci., 216, 320 (2008).

16. C. S. Gittleman, F. D. Coms, and Y.-H. Lai, "Membrane Durability: Physical and Chemical Degradation." Polymer Electrolyte Fuel Cell Degradation, ed. M M. Mench, E. C. Kumbur, and T. N. Veziroglu (Academic Press, Boston) 15 (2012).

17. S. Erbach et al., Int. J. Hydrogen Energy, 44, 12760 (2019).

18. K. Goto, I. Rozhanskii, Y. Yamakawa, T. Otsuki, and Y. Naito, Polym. J., 41, 95 (2009).

19. Private communication, Japanese automotive industry representative (2016).

20. M. Gross, G. Maier, T. Fuller, S. MacKinnon, and C. Gittleman, "Design rules for the improvement of the performance of hydrocarbon-based membranes for proton exchange membrane fuel cells (PEMFC)." Handbook of Fuel Cells, ed. W. Vielstich, H. A. Gasteiger, and H. Yokokawa (Wiley-VCH, Chichester, United Kingdom) 5, 283 (2009).

21. V. A. Sethuraman, J. W. Weidner, A. T. Haug, and L. V. Protsailo, J. Electrochem. Soc., 155, B119 (2008)

22. R. Shimizu, K. Otsuji, A. Masuda, N. Sato, M. Kusakabe, A. Iiyama, K. Miyatake, and M. Uchida, J. Electrochem. Soc., 166, F3105 (2019).

23. L. Gubler, T. Nauser, F. D. Coms, Y.-H. Lai, and C. S. Gittleman, J. Electrochem Soc., 165, F3100 (2018).

24. J. Miyake, M. Kusakabe, A. Tsutsumida, and K. Miyatake, ACS Appl. Energy Mater., 1, 1233 (2018).

25. L. Gubler, S. M. Dockheer, and W. H. Koppenol, J. Electrochem. Soc., 158, B755 (2011)

26. G. V. Buxton, C. L. Greenstock, W. P. Helman, and A. B. Ross, J. Phys. Chem. Ref Data, 17, 513 (1988)

27. P. Maruthamuthu, S. Padmaja, and R. E. Huie, Int. J. Chem. Kinet., 27, 605 (1995).

28. L. Gubler and W. H. Koppenol, "Hydrocarbon Proton Exchange Membranes." The Chemistry of Membranes Used in Fuel Cells: Degradation and Stabilization, ed. S. Schlick (Wiley, New York, NY) 107 (2018).

29. L. Gubler and W. H. Koppenol, J. Electrochem. Soc., 159, B211 (2012).

30. F. D. Coms, H. Liu, and J. E. Owejan, ECS Trans., 16, 1735 (2008)

31. T. Nauser and J. M. Gebicki, Essays Biochem., 64, 67 (2019).

32. M. Jonsson, "Redox Chemistry and Energetics of Radical Cations of Substituted Benzenes." Radiation Chemistry. Present Status and Future Trends, ed. C. D. Jonah and B. S. M. Rao (Elsevier, Amsterdam) 319 (2001).

33. S. M. Dockheer, L. Gubler, P. L. Bounds, A. S. Domazou, G. G. Scherer, A. Wokaun, and W. H. Koppenol, Phys. Chem. Chem. Phys., 12, 11609 (2010).

34. A. B. Das, T. Nauser, W. H. Koppenol, A. J. Kettle, C. C. Winterbourn, and P. Nagy, J. Free Radicals Biol. Med., 70, 86 (2014).

35. G. Hübner and E. Roduner, J. Mater. Chem., 9, 409 (1999).

36. S. M. Dockheer, L. Gubler, and W. H. Koppenol, Phys. Chem. Chem. Phys., 15, 4975 (2013)

37. K. Sehested and J. Holcman, J. Phys. Chem., 82, 651 (1978).

38. J. Holcman, Formation and reactions of radical cations of substituted benzenes in aqueous media. A pulse radiolysis study Report No. 1947, Ris $\emptyset$ National
Laboratory, Denmark (1977), https://orbit.dtu.dk/en/publications/formation-andreactions-of-radical-cations-of-substituted-benzene.

39. T. M. Nolte, T. Nauser, and L. Gubler, Phys. Chem. Chem. Phys., 22, 4516 (2020).

40. L. Morss, Standard Potentials in Aqueous Solution, ed. A. J. Bard, R. Parsons, and J. Jordan (Marcel Dekker, New York, NY) 587 (1985)

41. D. A. Armstrong, R. E. Huie, W. H. Koppenol, S. V. Lymar, G. Merényi, P. Neta, B. Ruscic, D. M. Stanbury, S. Steenken, and P. Wardman, Pure Appl. Chem., 87, 1139 (2015).

42. S. M. Dockheer, L. Gubler, and W. H. Koppenol, Phys. Chem. Chem. Phys., 13, 12429 (2011).

43. T. Nauser, G. Casi, W. H. Koppenol, and C. Schöneich, J. Phys. Chem. B, 112 15034 (2008).

44. K.-D. Asmus, Methods Enzymol., 105, 167 (1984).

45. R. H. Schuler, T. I. Balkas, and J. H. Fendler, J. Phys. Chem., 74, 4497 (1970).

46. IUPAC, Compendium of Chemical Terminology 2nd. ed. (1997), (the 'Gold Book'), Compiled by, ed. A. D. McNaught and A. Wilkinson (Blackwell Scientific Publications) Online version (2019-) created by S. J. Chalk, (Oxford)(https:// goldbook.iupac.org/terms/view/S06033).

47. L. Gubler, T. Nolte, and T. Nauser, ECS Trans., 86, 369 (2018).

48. G. Czapski, B. H. J. Bielski, and N. Sutin, J. Phys. Chem., 67, 201 (1963).

49. P. O'Neill, S. Steenken, and D. Schulte-Frohlinde, J. Phys. Chem., 79, 2773 (1975).

50. K. Sehested, J. Holcman, and E. J. Hart, J. Phys. Chem., 81, 1363 (1977).

51. A. M. Baker, S. K. Babu, R. Mukundan, S. G. Advani, A. K. Prasad, D. Spernjak, and R. L. Borup, J. Electrochem. Soc., 164, F1272 (2017).

52. A. M. Baker, S. T. D. Williams, R. Mukundan, D. Spernjak, S. G. Advani, A. K. Prasad, and R. L. Borup, J Mater Chem A , 5, 15073 (2017).

53. J. Park and D. Kim, J. Membr. Sci., 469, 238 (2014).

54. J. Park, Y. Park, and D. Kim, J. Polym. Sci., Part A: Polym. Chem., 57, 101 (2019).

55. X. Fang, X. Pan, A. Rahmann, H.-P. Schuchmann, and C. von Sonntag, Chem. Eur. J., 1, 423 (1995).

56. N. Santschi and T. Nauser, Chem Phys Chem, 18, 2973 (2017).

57. A. J. Elliot, D. R. McCracken, G. V. Buxton, and N. D. Wood, J. Chem. Soc Faraday Trans., 86, 1539 (1990).

58. R. W. Matthews, H. A. Mahlmann, and T. J. Sworski, J. Phys. Chem., 74, 2475 (1970).

59. A. Paul, M. Mulholland, and M. S. Zaman, J. Mater. Sci., 11, 2082 (1976)

60. S. M. Dockheer, L. Gubler, and W. H. Koppenol, unpublished results.

61. L. Gubler, "Radiation Grafted Membranes for Polymer Electrolyte Fuel Cells." Department of Chemistry and Applied Biosciences, ETH Zürich (2016), Habilitation Thesis https://www.research-collection.ethz.ch/handle/20.500.11850/ 190017.

62. M. Kranenburg, M. V. Ciriano, A. Cherkasov, and P. Mulder, J. Phys. Chem. A, 104, 915 (2000)

63. F. D. Coms and A. B. McQuarters, ECS Trans., 86, 395 (2018). 